\title{
Şanlıurfa'daki Eczanelerde ve Aktarlarda Fitoterapi Amaçlı Satılan Bitkiler
}

\author{
Haşim ÖTNÜ1, Hasan AKAN2 \\ ${ }^{1}$ Şanlıurfa Mehmet Akif İnan Eğitim ve Araştırma Hastanesi, Şanlıurfa, ${ }^{2}$ Harran Üniversitesi, Fen Edeb. Fak., Biyoloji Bölümü, Şanlıurfa \\ ${ }^{1}$ https://orcid.org/0000-0003-2335-4170, ${ }^{2}$ https://orcid.org/0000-0002-3033-4349 \\ $\bowtie$ : hakan@harran.edu.tr
}

\section{ÖZET}

$\mathrm{Bu}$ çalışma, 2018-2019 yıllarında Şanlıurfa merkez ilçelerindeki eczane ve aktarlarda fitoterapi amaçlı satılan bitkisel ürünlerin tespiti için yapılmıştır. Şanlıurfa'da bulunan 48 eczane ve 13 aktar dükkânında araştırma yapılmış olup, 144 bitkinin fitoterapi amaçlı satıldığ satılan 84 terkibin muhteviyatı, üretici firmaları, kullanım amaçları ve drogların bilimsel isimleri de belirlenmiştir. Araştırma yapılan eczane ve aktarlardaki bitki ve terkiplerin fotoğrafları da çekilmiştir. Tespit edilen bitki ve bileşimlerin bilimsel isimleri ile yöresel isimlerine de yer verilmiştir.

\section{Araştırma Makalesi}

Makale Tarihçesi

Geliş Tarihi : 11.02 .2020

Kabul Tarihi : 09.04.2020

Anahtar Kelimeler

Aktar

Eczane

Fitoterapi

Şanlıurfa

Şifalı Bitkiler

\section{Plants Sold For Phytotheraphy in Pharmacies and Herbalists of Şanlıurfa}

\section{ABSTRACT}

This study was carried out to determine the phytotherapy products sold in pharmacy and herbal medicine in Sanliurfa in 2018-2019. Research was conducted in 48 pharmacies and 13 transfer shops in Şanlıurfa and 144 plants that were sold for phytotherapy. In addition, the contents of the 84 compounds sold for phytotherapy purposes, manufacturer companies, uses and the scientific names of the drugs were determined. Photographs of plants and compositions in the pharmacy and herbal products were also taken. The scientific names and local names of the plants and compositions identified were also included.

\section{Research Article}

$\begin{array}{ll}\text { Article History } & \\ \text { Received } & : 11.02 .2020 \\ \text { Accepted } & : 09.04 .2020\end{array}$

Keywords

Herbalist

Medicinal Plants

Pharmacy

Phytotherapy

Şanliurfa

To Cite : Ötnü H, Akan H 2020. Şanlıurfa'daki Eczanelerde ve Aktarlarda Fitoterapi Amaçlı Satılan Bitkiler. KSÜ Tarım ve Doğa Derg 23 (4): 947-965. DOI: 10.18016/ksutarimdoga.vi.688167.

\section{GİRIŞ}

Yunanca kaynaklı olan fitoterapi, phyton=bitki ve therapeia=hizmet etmek, iyileştirmek, tedavi etmek kelimelerinin birleştirilmesinden meydana gelmektedir. Fitoterapi, bitkisel kökenli ilaçların tedavide kullanılmasını araştıran bir bilim dalıdır (Çubukçu ve ark., 2002). İnsanların bitkilerle olan ilişkisi geçmişten beri gelen bir durumdur. Insanlar açlık, sağlık ve çevreye olan katkılarından dolayı bitkilere yönelmiş, zaman içerisinde bu bitkiler deneme yanılma yollarıyla insan hayatında büyük önem kazanmışlardır. İlk çağlardan kalan arkeolojik bulgulara göre insanlar, sağlık sorunlarını gidermek için bitkileri kullanmışlardır (Heinrich ve ark., 2004; Faydaoğlu ve Sürücüoğlu, 2011). Günümüzde mevcut ilaçların 1/4'i bitkisel kökenlidir ve bunların birçoğunda bitkiden elde edilmek istenen etken madde, laboratuvar ortaminda elde edilmektedir. Son yıllarda sentetik ilaçlarla meydana gelebilen ciddi yan etkilerin yol açtığı medikal ve ekonomik sorunlar, yan etkiden arınmış olduğu düşüncesi gibi birçok etmene bağlı olarak bitkisel tedaviyi yeniden popüler duruma getirmiştir (Sarışen ve Çalışkan, 2005). Türkiye'nin hemen her bölgesinde, özellikle şifalı bitkilerin etnobotanik kullanımları ile ilgili bilgiler kuşaktan kuşağa aktarılarak gelmiştir (Yıldırımlı, 2004).

Bugün yeryüzünde bulunan bitki türü sayısının 250.000-500.000 arasında olduğu kabul edilmektedir. Dünya Sağlık Örgütü (WHO) kayıtlarına göre dünya nüfusunun büyük bir bölümü (\%70-80) tedavi veya korunmak amacıyla "geleneksel tıp"tan yararlanmaktadır (Kırıcı, 2015). Bu amaçla yararlanılan tıbbi bitki türlerinin 70.000 kadar olduğu tahmin edilmektedir. WHO tarafindan 21.000 bitki türü, ilaç hazırlamak için uygun bulunmuştur (Başaran, 2012). Tibbi bitkilerden yararlanılarak hastalıkları tedavi etme alışkanlıkları, günümüzde "alternatif tıp", "geleneksel tıp" ya da "tamamlayıcı tıp" adı altında giderek artmaktadır (Ersöz, 2012; Kırıcı, 2015). Baytop, "Türkiye'de Bitkilerle Tedavi” 
adlı kitabında, Türkiye'de doğal olarak yetişen tıbbi bitki türlerinin 600 kadar olduğunu belirtmiştir (Baytop, 1984).

Son zamanlarda Sağlık Bakanlığı tarafından Geleneksel ve Tamamlayıcı Tip Uygulamaları yönetmeliği yayımlanmıştır. Artık Türkiye'de de aktarların yanı sıra, sağlık bakanlığının onayı ile fitoterapi amaçlı satılan bitkiler eczanelerde de daha güvenli olarak yerini almış bulunmaktadır (Anonim, 2020a).

"Aktar" kelimesi Arapça'da droglar ya da tıbbi madde anlamina gelen "akarir" kelimesinden gelmektedir (Akbulut \& Özkan, 2016). İnsanlar aktarlardan sağlıkla ilgili tek tek, karışım halinde ya da hazır karışımlar halinde aldıkları drogları, tamamen doğal ve zararsiz olduğu düşüncesiyle sorgulamadan kullanmaktadırlar (Tulukçu ve Sağdıç, 2011). Ancak bilinenin aksine tıbbi bitkiler de zararl yan etkilere sahip olabileceğinden, tıbbi bitkilerle tedavi baharatçılara emanet edilemeyecek kadar önemli bir konudur (Bulut ve ark., 2017).

Şanlıurfa'da bitkilerle tedavi oldukça had safhadadır. Yerel halk çoğu zaman kocakarı ilaçlarından satılan bitkileri tercih etmektedir. Ancak, Sağlık Bakanlığınca da tedbirler alınmış olup, eczanelerde de tıbbi bitkilerin satışlarına daha sık yer verilmesi önerilmiştir (Ersin ve Aksoy, 2004).

Bu araştırmanın amacı; Şanlıurfa'daki eczanelerde ve aktarlarda fitoterapi amaçlı satılan bitkilerin tespiti, hangi hastalıkların tedavisinde tercih edildiği ve halkın tıbbi bitkilere olan ilgisinin araştırılmasıdır.

$\mathrm{Bu}$ çalışmanın fitoterapi alanında bir boşluğu dolduracağ kanaatindeyiz.

Literatür taramaları sonucu elde edilen fitoterapi ile alakalı araştırmalardan bazıları şunlardır;

Çini (1983), Başer ve ark. (1986), Yücecan (1988), Özel (1999), Ayanoğlu ve ark. (1999), Akan ve ark. (2004), Malyer ve ark. (2004), Akan ve Aslan (2005), Akan ve ark. (2005), Saraçoğlu ve Ergun (2006), Balos ve Akan (2007), Akan ve ark. (2008), Akan ve Balos (2008), Çömlekçioğlu ve Karaman (2008), Altan (2008), Bayramoğlu ve ark. (2009), Solmaz ve Eren (2009), Yapıcı ve ark. (2009), Koçtürk ve ark. (2009), Deniz ve ark. (2010), Saskara ve ark. (2010), Kendir ve Güvenç, (2010), Faydaoğlu ve Sürücüoğlu (2011), Tulukcu ve Sağdıç, (2011), Altay ve Karahan, (2012), Açıkgöz ve Demirkol (2012), Polat ve ark. (2012a), Polat ve ark. (2012b), Leblebici ve ark. (2012), Akan ve ark. (2013), Aslan (2013), Selvi ve ark. (2013), Sargin ve ark. (2013), Sicak ve ark. (2013), Demirez ve ark. (2014), Korkmaz ve ark. (2014), Uzun ve ark. (2014), Akan ve Ayaz, (2016), Akan ve Bakır Sade (2015), Kökçü ve ark. (2015), Altay ve ark. (2015), Adıgüzel ve ark. (2016), Volkan ve ark. (2016), Furkan (2016), Bulut ve ark. (2017), Ozhatay (2017), Kayıran ve Kırıcı (2019), Kaya ve ark. (2019), Alpınar ve Yazıcıoğlu (2019)'dır.

\section{MATERYAL ve METOT}

$\mathrm{Bu}$ çalışma, 2018-2019 yıllarında Şanlıurfa merkezindeki eczane ve aktarlarda fitoterapi amaçlı satılan bitkisel ürünlerin tespiti için yapılmıştır. Şanlıurfa kent merkezindeki Haliliye, Eyyübiye ve Karaköprü merkez ilçelerinde (Şekil 1) satılan tıbbi bitkilerin tespiti için belirli aralıklarla aktarlar ve eczaneler ziyaret edilmiştir. Kent merkezindeki pilot çalışma olarak seçilen 13 aktar ve 48 eczacı ile birebir görüşmeler yapılmıştır. Eczacı ve aktarların bu bitkileri hangi amaçla sattıklarını tespit etmek için önceden hazırlanmış "Bilgi kayıt formları" ile bilgiler derlenmiştir. Kaynak kişilere bitkinin yerel ismi, kullanım amacı, kullanılan kısmı ve kullanım şekli sorulmuştur.

$\mathrm{Bu}$ çalışmada fitoterapi amaçlı satılan 84 terkibin muhteviyatı, üretici firmaları, kullanım amaçları ve drogların bilimsel isimleri bulgular kısmında verilmiştir.

Materyal olarak aktarlarda ve eczanelerde satılan bitki örnekleri kullanılmış, satılan bitkilerden numuneler alınmış ve numunelerin bilimsel teşhisleri yapılmıştır. $\mathrm{Bu}$ bitkilerin teşhisinde Türkiye Florası'ndan (Davis, 1965-1985; Davis ve ark., 1988; Türkiye Florası cilt 11 (Güner ve ark., 2000) adlı eserlerden yararlanılmıştır. Bitkilerin geçerli isimleri (Anonim, 2020b)'ye göre verilmiştir. Teşhisinde zorluk çekilen bitki örnekleri için uzman akademisyenlerden destek alınmıştır. Bitki örneklerine araştırmacının numarası verilmiştir. Araştırmada elde edilen bitki drogları Harran Üniversitesi Fen-Edebiyat Fakültesi Herbaryumu (HARRAN)'nda saklanmaktadır.

\section{Araştırma Alanının Genel Özellikleri}

Şanlıurfa, Güneydoğu Anadolu Bölgesi'nin Orta Firat Bölümü'nde yer almaktadır. 2019 yılı sonu itibariyla İl nüfusu: 2.073.614'dir. Türk, Kürt, Arap ve Zaza başta olmak üzere farklı etnik kişilerin bir arada kardeşçe yaşadığ 1 bir şehirdir. İlin yüzölçümü $19.242 \mathrm{~km}^{2}$ dir. Şehrin ekonomik faaliyetleri başta tarım olmak üzere hayvancılık ve turizmdir.

İlin ortalama yükseltisi 518-900 metredir. İlin en yüksek noktası kuzeydoğusundaki Karacadağ (1919 m) sönmüş yanardağ kütlesidir.

Şanlıurfa ili Akdeniz iklim bölgesinin De Martonne metoduna göre "Yarı Kurak" iklim bölgesine girmektedir (Akman, 2011). Son 50 yılı kapsayan verilere göre Şanlıurfa ilinde yıllık ortalama sıcaklık $18,7{ }^{\circ} \mathrm{C}$ 'dir. Yııllık ortalama yağış miktarı ise 457,8 mm'dir (Anonim, 2010).

Zohary (1973)'e göre Güneydoğu Anadolu Bölgesi, İran-Turan Floristik Bölgesi'nin Mezopotamya Provensi'nde yer almaktadır. Bölgede otsu türler çoğunluk göstermektedir (Aydoğdu ve Akan, 2005; Balos ve Akan, 2007). 


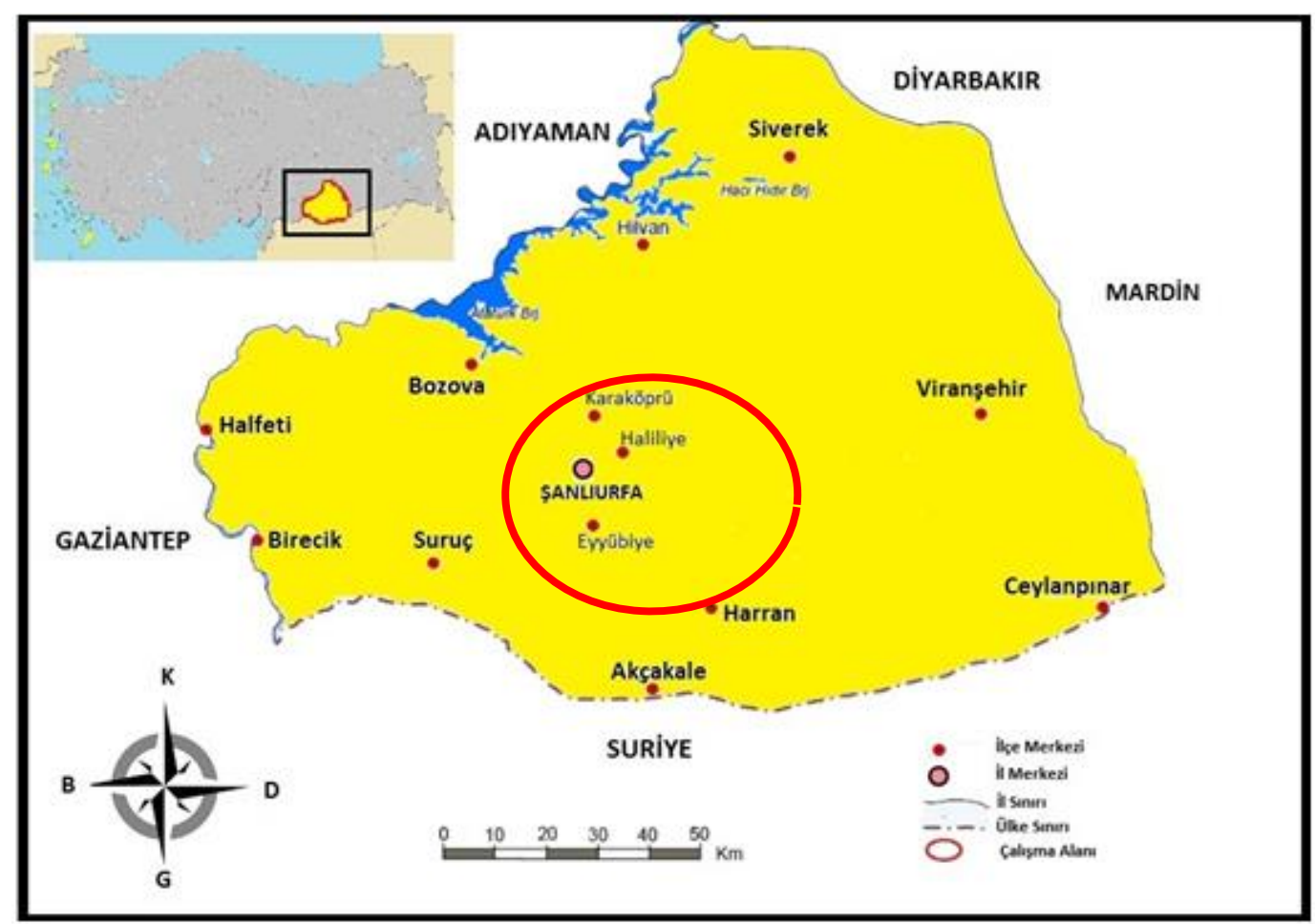

Şekil 1. Çalışma alanının haritası

Figure 1. Map of study area

\section{ARAŞTIRMA BULGULARI}

Bu çalışmada verilen bilgiler, Şanlıurfa'daki eczane ve aktarlarla yapılan görüşmeler sonucu elde edilen bilgilerdir.

Tüm hastalıklarınızda doktora danışmanız önerilmektedir. Şanlıurfa'daki aktar ve eczanelerde fitoterapi amaçlı satılan bitkiler, familya düzeyine göre alfabetik olarak Çizelge 1'de verilmiştir.

Şanlıurfa'daki eczane ve aktarlarda fitoterapi amaçlı satılan terkipler ve diğer bitkisel ürünler ise Çizelge 2'de gösterilmiştir.

\section{SONUC ve TARTIŞMA}

$\mathrm{Bu}$ çalışma 2018-2019 yılları arasında yapılmıştır. Şanlıurfa merkez ilçeleri olan Haliliye, Eyyübiye ve Karaköprü'deki eczane ve aktarlarda fitoterapi amaçlı satılan bitkisel ürünlerin tespiti amaçlanmıştır. Şanliurfa'da bulunan 48 eczane ve 13 aktar dükkânında, toplam 61 kaynak kişi ile görüşmeler yapılmış olup, 70 familyaya ait 144 bitkinin fitoterapi amaçlı satıldığı tespit edilmiştir. Ayrıca, bu çalışmada fitoterapi amaçlı satılan 84 terkibin muhteviyatı, üretici firmaları, kullanım amaçları ve drogların bilimsel isimleri de belirlenmiştir.

- Şanlıurfa'daki aktarlarda ve baharatçılarda fitoterapi amaçlı satılan tıbbi bitkiler gıda takviyesi veya baharat adı altında yasal olarak satılmaktadır. Ancak, araştırma yapılan aktar dükkânlarının genelinde fitoterapi amaçlı satılan çoğu bitkinin ambalajsız ve sağlıklı olmayan şartlarda olduğu görülmüştür. Aktarlardaki ürünlerin genellikle büyük çuvallarda muhafaza edildiği, naylon poşetlerle satıldığı ve sağlıksız şartlarda depolandığı tespit edilmiş, bitkilerin son kullanma tarihleri ile ilgili bir bilgiye yer vermedikleri de gözlemlenmiştir. Aktarlardaki tıbbi bitkilerin bir kısmı il genelinden toplanmakta, diğer yaygın tıbbi bitkiler ise İstanbul, Mersin ve Ankara'daki merkezlerden getirilmektedir. Eczanelerde tıbbi amaçlı satılan bitkisel ürünlerin tamamının İstanbul gibi metropol kentlerden veya yurt dışından ithal edildiği tespit edilmiştir.

- Çalışma sonuçları diğer araştırmalarla karşılaştırıldığında ortaya çıkan durum Çizelge 3'te verilmiştir. Bu çizelgede familya sayısının yanı sıra takson sayısı, terkip sayısı ve kaynak kişilerin sayısı da verilmiştir (Çizelge 3).

- Yapılan çalışmada en fazla takson içeren büyük familyalar sirasiyla; Lamiaceae (13), Rosaceae (11), Asteraceae (11), Apiaceae (9), Fabaceae (10), Malvaceae (6) ve Zingiberaceae (4)'dır. Şekil 2'de familyaların takson sayılarının yüzdelik dağılımı görülmektedir.

- Araştırmada en fazla takson içeren cinsler şunlardır; Prunus (3), Pistacia (2), Juniperus (2), Vaccinium (2), Lavandula (2), Mentha (2), Salvia (2), Hibiscus (2), Papaver (2) ve Pinus (2)'dir.

- Tıbbi çay olarak satılan bazı bitkiler; Capsella bursa-pastoris, Cydonia oblonga, Glycrrhiza glabra, Matricaria chamomilla var. chamomilla, Mentha pulegium, Rosa canina, Thymbra spicata var. spicata'dir. 
Çizelge 1: Şanlıurfa'daki aktar ve eczanelerde fitoterapi amaçlı satılan bitkilerin özellikleri

Table 1: Characteristics of plants sold for phytotherapy in pharmacies and herbalists of Sanliurfa

Çizelge 2. Şanlıurfa'daki eczane ve aktarlarda satılan terkipler ve diğer ürünler

\begin{tabular}{|c|c|c|c|c|c|}
\hline $\begin{array}{l}\text { Bitki Familyası } \\
\text { Plant Family }\end{array}$ & $\begin{array}{l}\text { Bitkinin Bilimsel adı } \\
\text { The Scientific name of the plant }\end{array}$ & $\begin{array}{l}\text { Yöresel isimleri } \\
\text { Local names }\end{array}$ & $\begin{array}{l}\text { Kullanilan kısımları } \\
\text { Parts used }\end{array}$ & $\begin{array}{l}\text { Kullanim amac1 } \\
\text { Purpose of usage }\end{array}$ & $\begin{array}{l}\text { Bitki } \\
\text { Örnek No: } \\
\text { Number } \\
\text { sample }\end{array}$ \\
\hline Adoxaceae & Sambucus nigra $L$. & Kara mürver & Çiçekleri & Grip ve soğuk algınlığına karşı kullanılmaktadır & HÖ 1117 \\
\hline Amaranthaceae & Chenopodium quinoa Willd. & Kinoa & Tohumu & $\begin{array}{l}\text { Zayıflama ve sindirimi kolaylaştırıcı amaçlar için } \\
\text { kullanılmaktadır }\end{array}$ & HÖ 1025 \\
\hline Amaryllidaceae & Allium sativum L. & Sarımsak & Meyvesi & 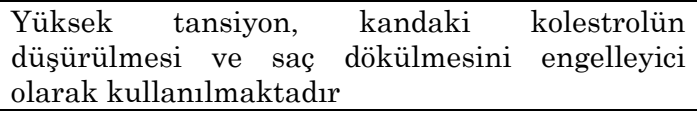 & HÖ 1084 \\
\hline Anacardiaceae & $\begin{array}{l}\text { Pistacia terebinthus } \quad \text { L. subsp. } \\
\text { terebinthus }\end{array}$ & $\begin{array}{l}\text { Menengiç, } \\
\text { Melengiç, } \\
\text { Citlembik, } \\
\text { Bittım } \\
\end{array}$ & $\begin{array}{l}\text { Meyveleri } \\
\text { Dalları } \\
\text { Yaprakları }\end{array}$ & $\begin{array}{l}\text { Vücuttaki toksinleri atmak için, ayrıca bıttım } \\
\text { sabunu ve kahvesinin elde edilmesinde de } \\
\text { kullanılmaktadır }\end{array}$ & HÖ 1082 \\
\hline Anacardiaceae & Pistacia vera $L$. & Antep fistığı & Meyve dış kabuğu & $\begin{array}{l}\text { Bağırsak iltihabı, mide ağrıları ve bronşitte } \\
\text { kullanılmaktadır }\end{array}$ & HÖ 1077 \\
\hline Anacardiaceae & Rhus coriaria L. & Sumak & Meyvesi & Mide rahatsızlıklarında kullanılmaktadır & HÖ 1091 \\
\hline Annonaceae & $\begin{array}{l}\text { Cananga odorata (Lam.) Hook.f. \& } \\
\text { Thomson }\end{array}$ & Ylang ylang & Bitkisel yă & Sakinleştirici olarak kullanılmaktadır & HÖ 1122 \\
\hline Apiaceae & Ammi visnaga (L.) Lam. & $\begin{array}{l}\text { Diş otu, Kürdan } \\
\text { otu, } \\
\text { Hıltan }\end{array}$ & $\begin{array}{l}\text { Çiçekleri } \\
\text { Tohumu }\end{array}$ & $\begin{array}{l}\text { Meyveleri kürdan yapımında, çiçekleri ise astım, } \\
\text { bronşit gibi solunum yolu hastalıklarında } \\
\text { kullanılmaktadır }\end{array}$ & HÖ 1108 \\
\hline Apiaceae & Anethum graveolens L. & Dereotu & $\begin{array}{l}\text { Yaprak } \\
\text { Kuru tozu }\end{array}$ & $\begin{array}{l}\text { Bağışıklık sistemini güçlendirici, ağız kokusu ve } \\
\text { mide rahatsızlıklarını giderici } \\
\text { kullanılmaktadır }\end{array}$ & HÖ 1086 \\
\hline Apiaceae & Coriandrum sativum L. & Kişniş & Meyve & $\begin{array}{l}\text { Mide salgılarını arttırıcı, iştah } \\
\text { hazmettirici amaçlı kullanılmaktadır }\end{array}$ & HÖ 1048 \\
\hline Apiaceae & Cumium cyminum L. & Kimyon & $\begin{array}{l}\text { Meyve } \\
\text { Tohum }\end{array}$ & 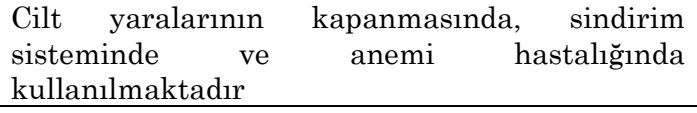 & HÖ 1030 \\
\hline Apiaceae & Eryngium campestre L. & Boğa dikeni & Toprak üstü kısımları & $\begin{array}{l}\text { Balgam ve ödem söktürücü, böbrek taşlarını } \\
\text { düşürmede kullanılmaktadır }\end{array}$ & HÖ 1110 \\
\hline Apiaceae & Ferula orientalis L. & Çakşır & Kök kabukları & $\begin{array}{l}\text { Cinsel gücü artırıcı ve kısırlığı önleyici olarak } \\
\text { kullanılmaktadır }\end{array}$ & HÖ 1021 \\
\hline Apiaceae & Foeniculum vulgare Mill. & Rezene & $\begin{array}{l}\text { Meyveleri } \\
\text { Uçucu yağı }\end{array}$ & $\begin{array}{l}\text { İnfüzyon yoluyla yapılan çay anne sütünü } \\
\text { arttırıcı, süt çocuklarında mide ve bağırsak } \\
\text { gazlarının gidericiliğinde kullanılmaktadır }\end{array}$ & HÖ 1043 \\
\hline
\end{tabular}




\begin{tabular}{|c|c|c|c|c|c|}
\hline Apiaceae & Petroselinum crispum (Mill.) Fuss & Maydanoz & Toprak üstü kısımları & $\begin{array}{l}\text { Karaciğer ve böbrek rahatsızlıkları ve stresi } \\
\text { önlemede kullanılmaktadır }\end{array}$ & HÖ 1027 \\
\hline Apiaceae & Pimpinella anisum L. & Anason & Meyveleri & $\begin{array}{l}\text { Gaz giderici, spazm azaltıcı etkiler ve iştahsızlık } \\
\text { için kullanılmaktadır }\end{array}$ & HÖ 1012 \\
\hline Aquifoliaceae & Ilex paraguariensis A.St.-Hil. & Mate & Yaprakları & $\begin{array}{l}\text { Zihinsel yorgunluğa karşı uyarıcı ve zayıflama } \\
\text { amaçlı kullanılmaktadır }\end{array}$ & HÖ 1111 \\
\hline Araliaceae & Hedera helix L. & Duvar sarmaşı̆̆ & $\begin{array}{l}\text { Yaprak } \\
\text { Şurup } \\
\end{array}$ & Öksürüğü engellemede kullanılmaktadır & HÖ 1140 \\
\hline Araliaceae & Panax ginseng C.A. Meyer. & Ginseng & $\begin{array}{l}\text { Kökü, } \\
\text { Hazır jel } \\
\text { Kapsül }\end{array}$ & $\begin{array}{l}\text { Cinsel yetersizliğe karşı, yorgunluk, } \\
\text { performansı artırıcısel } \\
\text { kullanılmaktadır }\end{array}$ & HÖ 1105 \\
\hline Arecaceae & Cocos nucifera L. & Hindistan cevizi & Bitkisel yağı & $\begin{array}{l}\text { Saçı canlı tutma ve nemlendirme özelliği için } \\
\text { kullanılmaktadır }\end{array}$ & HÖ 1136 \\
\hline Asteraceae & Achillea oligocephala DC. & Civanperçemi & $\begin{array}{l}\text { Çiçek } \\
\text { Toprak üstü kısmı } \\
\text { Uçucu yağ }\end{array}$ & $\begin{array}{l}\text { Sancı kesici, iltihap kurutucu, gaz söktürücü, } \\
\text { özellikle basur yaralarını iyileştirici amaçlar için } \\
\text { kullanılmaktadır }\end{array}$ & HÖ 1013 \\
\hline Asteraceae & Artemisia dracunculus L. & Tarhun & Yapraklar & $\begin{array}{l}\text { Uykusuzluk, İştah açıcı ve yaraları dezenfekte } \\
\text { edici olarak kullanılmaktadır }\end{array}$ & HÖ 1018 \\
\hline Asteraceae & Carthamus tinctorius L. & $\begin{array}{ll}\text { Aspir, } & \text { Haspir, } \\
\text { Yalanc1 } & \text { safran, } \\
\text { Zafur } & \\
\end{array}$ & Çiçek kısımları ve pistilleri & $\begin{array}{l}\text { idrar artırıcı, kabız giderici ve adet söktürücü } \\
\text { olarak kullanılmaktadır }\end{array}$ & HÖ1020 \\
\hline Asteraceae & $\begin{array}{l}\text { Cichorium glandulosum Boiss. et. } \\
\text { Huet }\end{array}$ & $\begin{array}{l}\text { Hindiba, } \\
\text { Karahindiba }\end{array}$ & Toprak üstü kısımları & 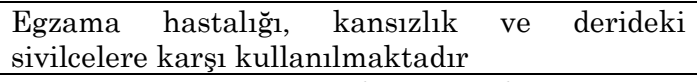 & HÖ 1009 \\
\hline Asteraceae & Cynara scolymus L. & Enginar & $\begin{array}{l}\text { Meyvesi } \\
\text { Yapraklar }\end{array}$ & $\begin{array}{l}\text { Sindirim sistemi hastalıklarında, kolesterol ve } \\
\text { tansiyonun dengelenmesinde kullanılmaktadır }\end{array}$ & HÖ 1103 \\
\hline Asteraceae & Echinacea purpurea (L.) Moench & $\begin{array}{l}\text { Ekinezya, } \\
\text { Kirpiotu }\end{array}$ & Yaprakları & $\begin{array}{l}\text { Bağışıklık sistemini güçlendirmek ve vücudun } \\
\text { enfeksiyonlara karşı direncini arttırmak için } \\
\text { kullanılmaktadır }\end{array}$ & HÖ 1055 \\
\hline Asteraceae & $\begin{array}{l}\text { Gundelia tournefortii L. } \\
\text { (Aste }\end{array}$ & Kenger, Kereng & Toprak altı ve toprak üstü kısım & $\begin{array}{l}\text { Kenger sakızı diş etlerini kuvvetlendirmek için } \\
\text { gıda amaçlı satılmaktadır }\end{array}$ & HÖ 1112 \\
\hline Asteraceae & Helichrysum orientale (L.) DC. & $\begin{array}{l}\text { Altın Otu, Ölmez } \\
\text { çiçek }\end{array}$ & Çiçekler & $\begin{array}{l}\text { İdrar sökücü, böbrek ve mesane rahatsızlıkları } \\
\text { için }\end{array}$ & HÖ 1033 \\
\hline Asteraceae & $\begin{array}{l}\text { Matricaria chamomilla } \text { L. var. } \\
\text { chamomilla }\end{array}$ & $\begin{array}{l}\text { Papatya, } \\
\text { Mayıs papatyası }\end{array}$ & $\begin{array}{l}\text { Çiçekleri } \\
\text { Uçucu yağ }\end{array}$ & $\begin{array}{l}\text { Nezle ve grip, boğaz tahrişleri, ciltteki kaşıntı ve } \\
\text { kızarıklıkları gidermek için kullanılmaktadır }\end{array}$ & HÖ 1065 \\
\hline Asteraceae & Silybum marianum (L.) Gaertn. & Deve dikeni & Tohumu & $\begin{array}{l}\text { Karaciğer ve siroz hastalıklarına } \\
\text { kullanılmaktadır }\end{array}$ & HÖ 1128 \\
\hline Asteraceae & Tussilago farfara L. & Öksürük otu & $\begin{array}{l}\text { Yaprak } \\
\text { Şurup }\end{array}$ & $\begin{array}{lcr}\begin{array}{l}\text { Öksürük, balgam ve diğer solunum yolu } \\
\text { hastalıklarında }\end{array} & \text { yumuşatıcı } & \text { olarak } \\
\text { kullanılmaktadır } & & \\
\end{array}$ & HÖ 1058 \\
\hline Boraginaceae & $\begin{array}{l}\text { Alkanna tinctoria (L.) Tausch } \\
\text { subsp. tinctoria }\end{array}$ & $\begin{array}{l}\text { Havacıva otu, } \\
\text { Havaco,Havacı }\end{array}$ & Kökleri & $\begin{array}{l}\text { Kökü ile hazırlanan çay kabızlıktan kurtulmak } \\
\text { için kullanılmaktadır }\end{array}$ & HÖ 1006 \\
\hline
\end{tabular}




\begin{tabular}{|c|c|c|c|c|c|}
\hline Brassicaceae & Brassica rapa L. & Şalgam & $\begin{array}{l}\text { Meyve } \\
\text { Tohum }\end{array}$ & $\begin{array}{l}\text { Bu bitki iştah açıcı ve sindirim sistemi ile } \\
\text { bağırsak hareketlerini } \\
\text { kullanılmaktadır }\end{array}$ & HÖ 1067 \\
\hline Brassicaceae & Capsella bursa-pastoris (L.) Medik. & $\begin{array}{l}\text { Çobançantası, } \\
\text { Çıngıraklı ot, } \\
\text { Kuş otu }\end{array}$ & Toprak üstü kısımları & $\begin{array}{l}\text { Basur hastalığında ve regl dönemlerini } \\
\text { düzenleyici olarak tercih edilmektedir }\end{array}$ & HÖ 1089 \\
\hline Brassicaceae & Sinapis arvensis L. & Herdal, Hardal & Tohumları & Kuvvet macunları terkiplerinde kullanılmaktadır & HÖ 1071 \\
\hline Cannabaceae & Humulus lupulus L. & Şerbetçi otu & $\begin{array}{l}\text { Çiçek } \\
\text { Yaprak }\end{array}$ & $\begin{array}{l}\text { Sakinleştirici ve rahatlatıcı amaçlar için } \\
\text { kullanılmaktadır }\end{array}$ & HÖ 1131 \\
\hline Capparaceae & Capparis sicula Veill. subsp. sicula & Kebere, kapari & Tomurcukları Meyveleri & $\begin{array}{lrlll}\text { Kuvvet verici } & \text { ve } & \text { afrodizyak } & \text { amaçlı } \\
\text { kullanılmaktadır }\end{array}$ & HÖ 1059 \\
\hline Caprifoliaceae & Valeriana officinalis L. & Kediotu & Ezilmiş kökleri & $\begin{array}{l}\text { Yatıştırıcı, spazm giderici, sinirsel uykusuzluklar } \\
\text { ve çarpıntılara karşı kullanılmaktadır }\end{array}$ & HÖ 1016 \\
\hline Comberateceae & $\begin{array}{l}\text { Terminalia citrina } \text { Roxb. ex. } \\
\text { Fleming }\end{array}$ & Sarı halile & Meyve & $\begin{array}{l}\text { İshal kesici, vücut direnci ve cinsel gücü arttırıcı } \\
\text { amaçlar için kullanılmaktadır }\end{array}$ & HÖ 1139 \\
\hline Convolvulaceae & $\begin{array}{l}\text { Cuscuta babylonica Aucher ex } \\
\text { Choisy }\end{array}$ & $\begin{array}{l}\text { Küşüt, İkşut, } \\
\text { Küsküt, } \\
\text { Gelinsaçı }\end{array}$ & Yaprakları & $\begin{array}{l}\text { Karaciğer rahatsızlıkları, yeni doğan bebek ve } \\
\text { annelerin fizyolojik sarılık tedavisinde } \\
\text { kullanılmaktadır }\end{array}$ & HÖ 1107 \\
\hline Cucurbitaceae & Momordica charantia L. & Kudretnarı & Meyve & $\begin{array}{l}\text { Mide rahatsızlıklarında, kan şekerini } \\
\text { düzenlemede, Cilt ve saç sağlığını koruma amaçlı } \\
\text { kullanılmaktadır }\end{array}$ & HÖ 1001 \\
\hline Cupressaceae & $\begin{array}{l}\text { Juniperus communis L. var. } \\
\text { communis }\end{array}$ & Ardıç & $\begin{array}{l}\text { Meyve } \\
\text { Uçucu yağ } \\
\text { Tentür }\end{array}$ & $\begin{array}{l}\text { Balgam çıkartıcı, deri hastalıkları ve kandaki } \\
\text { şeker miktarının } \\
\text { kullanılmaktadır }\end{array}$ & HÖ 1010 \\
\hline Cupressaceae & $\begin{array}{l}\text { Juniperus oxycedrus L. subsp. } \\
\text { oxycedrus }\end{array}$ & Adi ardıç & Meyveleri & $\begin{array}{l}\text { Iltihaplı yaraların tedavisi, midevi rahatsızlıklar } \\
\text { ve zayıflamak için kullanılmaktadır }\end{array}$ & НÖ 1011 \\
\hline Cyperaceae & Cyperus rotundus L. & $\begin{array}{l}\text { Topalak, } \\
\text { Toparlak }\end{array}$ & Yumruları & $\begin{array}{l}\text { Kabızlık ve kalın bağırsak iltihabını önlemede } \\
\text { kullanılmaktadır }\end{array}$ & HÖ 1070 \\
\hline Elaeagnaceae & Elaeagnus angustifolia L. & İğde & Meyvesi & $\begin{array}{l}\begin{array}{l}\text { Zihin açıcı ve ateş } \\
\text { kullanılmaktadırşürücü }\end{array} \\
\text { olarak }\end{array}$ & HÖ 1090 \\
\hline Equisetaceae & Equisetum arvense L. & $\begin{array}{l}\text { Atkuyruğu, } \\
\text { Kırkkilitotu }\end{array}$ & Toprak üstü kısımları & $\begin{array}{l}\text { İdrar söktürücü, ödemleri çözücü ve öksürük } \\
\text { yatıştırıcı olarak kullanılmaktadır }\end{array}$ & HÖ 1060 \\
\hline Ericaceae & Calluna vulgaris (L.) Hull & Funda & Yaprakları & Böbrek taşı düşürenlere önerilmektedir & HÖ 1044 \\
\hline Ericaceae & Vaccinium myrtillus L & $\begin{array}{l}\text { Yaban mersini, } \\
\text { Çoban üzümü }\end{array}$ & Meyve & $\begin{array}{l}\text { Kan şekerini düzenleyici, idrar yollarını } \\
\text { temizleyici olarak kullanılmaktadır }\end{array}$ & HÖ 1014 \\
\hline Ericaceae & Vaccinium macrocarpon Aiton & Turna yemişi & Meyve & İdrar yolu enfeksiyonlarında kullanılmaktadır & HÖ 1142 \\
\hline Fabaceae & Arachis hypogaea L. & Yer fistığı & Bitkisel yağ & $\begin{array}{l}\text { Bağışıklık sistemini güçlendirici, kolesterol } \\
\text { düzenleyici amaçlar için kullanılmaktadır }\end{array}$ & НÖ 1138 \\
\hline Fabaceae & Ceratonia siliqua L. & $\begin{array}{l}\text { Keçiboynuzu, } \\
\text { Harnup }\end{array}$ & $\begin{array}{l}\text { Kuru meyveler } \\
\text { Tohum }\end{array}$ & $\begin{array}{l}\text { Sperm arttırıcı ve kabızlık giderici amaçlar için } \\
\text { kullanılmaktadır }\end{array}$ & HÖ 1034 \\
\hline Fabaceae & Senna marilandica (L.) Link & Sinameki & Yaprak & $\begin{array}{l}\text { Kabızlık giderici, saçları güçlendirici amaçlar için } \\
\text { kullanılmaktadır }\end{array}$ & HÖ 1003 \\
\hline
\end{tabular}




\begin{tabular}{|c|c|c|c|c|c|}
\hline Fabaceae & $\begin{array}{l}\text { Senna alexandrina Mill. } \\
\text { L. }\end{array}$ & $\begin{array}{l}\text { Açlık otu, Deve } \\
\text { gözü, Erkek } \\
\text { sinameki }\end{array}$ & Yaprak & $\begin{array}{l}\text { Tokluk hissi vererek kilo } \\
\text { olmakta ve vermede yardımcı } \\
\text { kullanılmaktadır }\end{array}$ & HÖ 1126 \\
\hline Fabaceae & Glycyrrhiza glabra L. var. glabra & $\begin{array}{l}\text { Meyan, Biyan, } \\
\text { Biyam ball, Süs }\end{array}$ & Kökleri & $\begin{array}{l}\text { Balgam sökücü, göğüs yumuşatıcı, tat düzeltici, } \\
\text { öksürük ve spazmlara karşı, böbrek } \\
\text { rahatsızlıklarına karşı kullanılmaktadır. }\end{array}$ & HÖ 1079 \\
\hline Fabaceae & Lathyrus sativus L. & $\begin{array}{l}\text { Burçak, } \\
\text { Mürdümük }\end{array}$ & Tohumları & $\begin{array}{l}\text { İdrar yolları iltihaplarını giderici, cinsel gücü } \\
\text { artırıcı, kuvvet verici olarak kullanılmaktadır }\end{array}$ & HÖ 1045 \\
\hline Fabaceae & Trigonella foenum-graecum L. & $\begin{array}{l}\text { Çemen otu, } \\
\text { Boyotu, Buyotu }\end{array}$ & Tohumları & $\begin{array}{l}\text { Göğüs yumuşatıcı, balgam söktürücü ve kuvvet } \\
\text { verici olarak kullanılmaktadır }\end{array}$ & HÖ 1072 \\
\hline Fabaceae & Vicia faba L. & $\begin{array}{l}\text { Bakla, } \\
\text { baklası }\end{array}$ & Meyvesi & $\begin{array}{l}\text { Böbrek iltihabında, şeker hastalığı tedavisinde } \\
\text { kullanılmaktadır }\end{array}$ & HÖ 1031 \\
\hline Fagaceae & Corylus avellana L. var. avellana & Findık & Meyvesi & $\begin{array}{l}\text { Kuvvet verici ve hafızayı güçlendirmek amaçlı } \\
\text { kullanılmaktadır }\end{array}$ & HÖ 1085 \\
\hline Fagaceae & Quercus infectoria G. Olivier & Mazı meşesi & Mazisı & $\begin{array}{l}\text { Dâhilen ishal kesici, haricen ise basurda kan } \\
\text { durdurucu olarak kullanılmaktadır }\end{array}$ & HÖ 1007 \\
\hline Ginkgoaceae & Ginkgo biloba L. & Mabet ağacı & Yapraklar & $\begin{array}{l}\text { Hafızayı güçlendirici, cinsel isteğin artmasına } \\
\text { yardımcı olarak kullanılmaktadır }\end{array}$ & HÖ 1106 \\
\hline Hypericaceae & Hypericum perforatum L. & Sarı kantaron & Toprak üstü kısımları & $\begin{array}{llll}\text { İshal kesici, ayrıca depresyon } & \text { ve } & \text { ruhsal } \\
\text { çöküntüler için kullanılmaktadır } & & \\
\end{array}$ & HÖ 1093 \\
\hline Iridaceae & Crocus sativus L. & Zahferan, Safran & Stigma & Depresyon tedavisinde kullanılmaktadır & HÖ 1008 \\
\hline Juglandaecea & Juglans regia L. & Ceviz & $\begin{array}{l}\text { Meyve } \\
\text { Meyve kabukları } \\
\text { Yaprakları } \\
\end{array}$ & $\begin{array}{l}\text { Meyveleri kan şekerini düşürücü, kuvvet verici, } \\
\text { meyve kabukları ise haricen deri hastalıklarında } \\
\text { ve saç dökülmesinde kullanılmaktadır }\end{array}$ & HÖ 1081 \\
\hline Lamiaceae & Lamium album L. subsp. album & Ballıbaba & Kökü & $\begin{array}{l}\text { Kabızlığı önleyici, kuvvet verici, kan temizleyici } \\
\text { ve yaraları iyi edici olarak kullanılmaktadır }\end{array}$ & HÖ 1057 \\
\hline Lamiaceae & Lavandula angustifolia Mill. & Lavanta & Çiçekli gövde & $\begin{array}{l}\text { Saç dökülmesine karşı, sedef ve derideki lekelere } \\
\text { karşı pomat olarak kullanılmaktadır }\end{array}$ & HÖ 1094 \\
\hline Lamiaceae & Lavandula stoechas L. & $\begin{array}{l}\text { Karabaş otu, } \\
\text { Afat, Korku otu }\end{array}$ & Toprak üstü kısımları & $\begin{array}{l}\text { İdrar artırıcı, nefes açıcı ve depresyona karşı, } \\
\text { ayrıca, çocuklarda korku giderici amaç için } \\
\text { kullanılmaktadır }\end{array}$ & HÖ 1064 \\
\hline Lamiaceae & $\begin{array}{l}\text { Melissa officinalis } \quad \text { L. subsp. } \\
\text { officinalis }\end{array}$ & $\begin{array}{l}\text { Melisa, Oğulotu, } \\
\text { Acem otu }\end{array}$ & $\begin{array}{l}\text { Taze ve kurutulmuş yaprak } \\
\text { Uçucu yağ }\end{array}$ & $\begin{array}{l}\text { Kalp rahatsılıklarına iyileştirici, sinir } \\
\text { hastalıklarında yatıştırıcı, nefes darlığını giderici } \\
\text { amaçlar için kullanılmaktadır }\end{array}$ & HÖ 1083 \\
\hline Lamiaceae & Mentha piperita L. & Nane & Toprak üstü kısımları & $\begin{array}{l}\text { Mide rahatsızlıklarında ve vücut ateşinin } \\
\text { düşürülmesinde kullanılmaktadır }\end{array}$ & HÖ 1092 \\
\hline Lamiaceae & Mentha pulegium L. & $\begin{array}{l}\text { Kaya yarpuzu, } \\
\text { Punge tahte, } \\
\text { Tüylü nane }\end{array}$ & Toprak üstü kısımları & $\begin{array}{l}\text { Nefes açıcı ve mide rahatsızlıklarını giderici } \\
\text { amaçlar için kullanılmaktadır }\end{array}$ & HÖ 1056 \\
\hline Lamiaceae & Rosmarinus officinalis L. & Kuşdili, Biberiye & Yaprakları & $\begin{array}{l}\text { Kış aylarında üst solunum yolu enfeksiyonları } \\
\text { hastalıklarında kullanılmaktadır }\end{array}$ & HÖ 1074 \\
\hline
\end{tabular}




\begin{tabular}{|c|c|c|c|c|c|}
\hline Lamiaceae & Salvia fruticosa Mill. & Adaçayı & $\begin{array}{l}\text { Toprak üstü kısımları } \\
\text { Yaprakları }\end{array}$ & 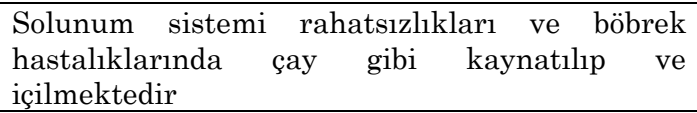 & HÖ 1023 \\
\hline Lamiaceae & Salvia hispanica L. & Chia tohumu & Tohumu & $\begin{array}{l}\text { Beyin ve kalp hastalıklarında, ayrıca tokluk hissi } \\
\text { verdiğinden zayıflamak amaçlı kullanılmaktadır }\end{array}$ & HÖ 1125 \\
\hline Lamiaceae & Teucrium polium L. & $\begin{array}{l}\text { Yavşan otu, } \\
\text { Talik, } \\
\text { Meryemhort }\end{array}$ & Toprak üstü kısımları & $\begin{array}{l}\text { Mide rahatsızlıkları, özellikle karın ağrılarında } \\
\text { yaygın olarak kullanılmaktadır }\end{array}$ & HÖ 1053 \\
\hline Lamiaceae & Thymbra spicata L. var. spicata & $\begin{array}{lr}\text { Cahter, } & \text { Zahter, } \\
\text { Zater, } & \text { Kara } \\
\text { kekik, } & \\
\end{array}$ & Toprak üstü kısımları & $\begin{array}{l}\text { Bronşit ve sinüzit } \quad \text { rahatsızlıklarında } \\
\text { kullanılmaktadır }\end{array}$ & HÖ 1095 \\
\hline Lamiaceae & Thymus fallax Fisch. \& C.A. Mey & Kekik & Toprak üstü kısımları & $\begin{array}{l}\text { Hazımsızlık giderici, balgam söktürücü ve } \\
\text { öksürük kesici olarak kullanılmaktadır }\end{array}$ & HÖ 1076 \\
\hline Lamiaceae & Vitex agnus-castus L. & Hayıt & Tohumları & $\begin{array}{l}\text { Anne sütünü arttırıcı ve hormon dengeleyici } \\
\text { özellikler için kullanılmaktadır }\end{array}$ & HÖ 1075 \\
\hline Lauraceae & Cinnamomum verum J. Presl & Tarçın & Kabuk & $\begin{array}{l}\text { Kilo vermeye yardımcı, kan şekerini dengeleyici } \\
\text { olarak kullanılmaktadır }\end{array}$ & HÖ 1004 \\
\hline Lauraceae & Laurus nobilis L. & Defne & Yaprak ve meyveleri & $\begin{array}{l}\text { Defne yağı haricen romatizma ağrılarını dindirici, } \\
\text { vücut parazitlerini öldürücü } \\
\text { kullanılmaktadır }\end{array}$ & HÖ 1026 \\
\hline Lauraceae & Persea americana Mill. & Avokado & Meyveleri & $\begin{array}{l}\text { Meyvelerin yağlı mezokarp kısmı ezilip limon } \\
\text { olarak sıkılır. Meyvelerden elde edilen yağ cilt } \\
\text { bakımında kullanılmaktadır }\end{array}$ & HÖ 1029 \\
\hline Linaceae & Linum usitatissimum L. & Keten & Tohum & $\begin{array}{lcccc}\begin{array}{l}\text { Tokluk } \\
\text { kullanılmaktadır }\end{array} & \text { verip } & \text { zayıflamak } & \text { için } \\
\end{array}$ & HÖ 1134 \\
\hline Lythraceae & Punica granatum L. & Nar & Bitkisel yağı & $\begin{array}{l}\text { Yaşlanmaya ve kırışıklıklara karşı etkili olarak } \\
\text { kullanılmaktadır }\end{array}$ & HÖ 1120 \\
\hline Malpighiaceae & Malpighia emarginata DC. & Barbados kirazı & Meyve & $\begin{array}{l}\text { Grip, nezle gibi soğuk algınlıklarına karşı } \\
\text { kullanılmaktadır }\end{array}$ & HÖ 1141 \\
\hline Malvaceae & $\begin{array}{l}\text { Abelmoschus esculentus } \\
\text { Moench }\end{array}$ & Bamya & Meyveler & $\begin{array}{l}\text { Bağırsakları yumuşatıcı, mide ve göğüs } \\
\text { yumuşatıcı olarak kullanılmaktadır }\end{array}$ & HÖ 1047 \\
\hline Malvaceae & Althaea officinalis L. & Hatmi, Hiro. & Çiçek ve yaprakları & $\begin{array}{l}\text { Akciğer rahatsızlıkları, nezle ve bronşit } \\
\text { tedavisinde kullanılır. Çiçekleri kaynatılıp, suyu } \\
\text { içilmektedir. Kaşıntıları dindirmek için bitkinin } \\
\text { yaprakları ılık halde cilde tatbik edilmektedir. }\end{array}$ & HÖ 1037 \\
\hline Malvaceae & Hibiscus sabdariffa L. & $\begin{array}{l}\text { Hibiskus, } \\
\text { Narçiçeği }\end{array}$ & Yaprak & $\begin{array}{l}\text { Bağışıklık sistemini güçlendirici ve özellikle kış } \\
\text { aylarında nezle ve grip gibi hastalıklara karşı } \\
\text { korunmaya yardımcı amaçlar için } \\
\text { kullanılmaktadır }\end{array}$ & HÖ 1127 \\
\hline Malvaceae & Malva sylvestris L. & $\begin{array}{l}\text { Kömeç, } \\
\text { Ebegümeci, } \\
\text { Develik, Tolik }\end{array}$ & Kurutulmuş toprak üstü kısımları & $\begin{array}{l}\text { Göğüs yumuşatıcı, öksürük kesici ve damar } \\
\text { tıkanıklığında kullanılmaktadır }\end{array}$ & HÖ 1032 \\
\hline
\end{tabular}




\begin{tabular}{|c|c|c|c|c|c|}
\hline Malvaceae & Theobroma cacao L. & Kakao yağı & Bitkisel yăg & $\begin{array}{lcccc}\begin{array}{l}\text { Dudak çatlakları } \\
\text { kullanılmaktadır. }\end{array} & \text { ve } & \text { sedef } & \text { yaralarında } \\
\end{array}$ & HÖ 1123 \\
\hline Malvaceae & $\begin{array}{l}\text { Tilia platyphyllos Scop. subsp. } \\
\text { platyphyllos }\end{array}$ & Ihlamur & $\begin{array}{l}\text { Yaprak } \\
\text { Çiçek }\end{array}$ & $\begin{array}{llll}\begin{array}{l}\text { Öksürüğe, gribe } \\
\text { kullanılmaktadır }\end{array} & \text { ve } & \text { nezleye } & \text { karşı } \\
\end{array}$ & HÖ 1066 \\
\hline Moraceae & Morus nigra $\mathrm{L}$. & Karadut & Meyve & $\begin{array}{l}\text { Aft, mantar ve ağız içi } \\
\text { iyileştirilmesinde kullanılmaktadır }\end{array}$ & HÖ 1109 \\
\hline Moringaceae & Moringa oleifera Lam. & Moringa & Yaprakları & Zayıflama amacıyla kullanılmaktadır & HÖ 1133 \\
\hline Myrtaceae & $\begin{array}{l}\text { Melaleuca alternifolia (Maiden \& } \\
\text { Betch) Cheel }\end{array}$ & $\begin{array}{l}\text { Çay ağacı, } \\
\text { Hint defnesi }\end{array}$ & Bitkisel yağı & $\begin{array}{l}\text { Akne ve sivilce gibi cilt sorunlarına karşı } \\
\text { kullanılmaktadır }\end{array}$ & HÖ 1118 \\
\hline Myrtaceae & Myrtus communis L. & $\begin{array}{l}\text { Mersin, } \\
\text { Murt }\end{array}$ & Yaprakları & $\begin{array}{llcc}\text { Gögüs hastalıkları ve idrar } & \text { yolu } \\
\text { rahatsızlıklarında kullanılmaktadır } & \end{array}$ & HÖ 1098 \\
\hline Myrtaceae & $\begin{array}{l}\text { Syzygium aromaticum (L.) Merr. \& } \\
\text { L.M. Perry }\end{array}$ & Karanfil & $\begin{array}{l}\text { Çiçek } \\
\text { Kök } \\
\text { Yaprak }\end{array}$ & $\begin{array}{l}\text { Hem baharat hem de ağız kokusunu gidermek ve } \\
\text { çaya hoş koku vermek için kullanılmaktadır }\end{array}$ & HÖ 1036 \\
\hline Nitrariaceae & Peganum harmala L. & Üzerlik & Tohumları & $\begin{array}{l}\text { Kurt düşürücü, adet söktürücü, uyuşturucu ve } \\
\text { soğuk algınlığına karşı kullanılmaktadır }\end{array}$ & HÖ 1002 \\
\hline Oleaceae & Olea europaea L. subsp. europaea & Zeytin & Yaprakları & $\begin{array}{l}\text { Sindirim sistemi, bağışıklık ve kalp sağlığı için } \\
\text { kullanılmaktadır }\end{array}$ & HÖ 1124 \\
\hline Onagraceae & Epilobium angustifolium L. & Yakı otu & Yaprakları & Prostat tedavisinde kullanılmaktadır & HÖ 1116 \\
\hline Papaveraceae & Fumaria officinalis L. & Şahtere & Toprak üstü kısımları & $\begin{array}{l}\text { İdrar arttırıcı, yatıştırıcı ve sedefe } \\
\text { kullanılmaktadır }\end{array}$ & HÖ 1062 \\
\hline Papaveraceae & Papaver rhoeas L. & Gelincik & Çiçekleri & $\begin{array}{l}\text { Balgam söktürücü, göğüs yumuşatıcı ve küçük } \\
\text { çocuklara uyku verici olarak kullanılmaktadır }\end{array}$ & HÖ 1087 \\
\hline Papaveraceae & Papaver somniferum L. & Haşhaş & Yaprak, tohum & $\begin{array}{lcccc}\text { Haşhaş yaprakları } & \text { merhem } & \text { haline getirilip } \\
\text { ağrıan bölgeye } & \text { ağrıyı } & \text { kesmak için } \\
\text { kullanılmaktadır } & & & \\
\end{array}$ & HÖ 1041 \\
\hline Passifloraceae & Passiflora edulis Sims. & Çarkıfelek & Toprak üstü kısım & $\begin{array}{l}\text { Huzursuzluk, endişe, ruhsal } \\
\text { giderilmesinde ve ve uykusuzluk } \\
\text { kullanılmaktadır }\end{array}$ & HÖ 1130 \\
\hline Pedaliaceae & Sesamum indicum L. & $\begin{array}{l}\text { Susam, Küncü, } \\
\text { Künci }\end{array}$ & Tohumları & Kuvvet verici macunlara katılmaktadır & HÖ 1099 \\
\hline Pinaceae & Pinus brutia Ten. & Çam terebentin & Bitkisel yăg & $\begin{array}{l}\text { Cilt tedavisi ve saç dökülmesine karşı } \\
\text { kullanılmaktadır }\end{array}$ & HÖ 1119 \\
\hline Pinaceae & Pinus pinea L. & Çam fistığ & Tohumları & $\begin{array}{l}\text { Kuvvet verici ve diş ağrılarını dindirici amaçlar } \\
\text { için kullanılmaktadır }\end{array}$ & HÖ 1061 \\
\hline Piperaceae & Piper nigrum L. & Karabiber & Meyveleri, kabukları & $\begin{array}{lllll}\text { İştah açıcı ve gaz } & \text { söktürücü } & \text { olarak } \\
\text { kullanılmaktadır } & & & \\
\end{array}$ & HÖ 1049 \\
\hline Platanaceae & Platanus orientalis L. & Çinar & Gövde kabukları & Saç bakımı ve yanıklarda haricen kullanılmaktadır & HÖ 1097 \\
\hline Poaceae & Elymus repens (L.) Gould. & Ayrık otu & Kök, Rizom & $\begin{array}{l}\text { Böbrek ve mesanede meydana gelen taş ve } \\
\text { iltihapların tedavisinde kullanılmaktadır }\end{array}$ & HÖ 1101 \\
\hline Poaceae & Eragrostis tef (Zucc.) Trotter & Teff tohumu & Tohumları & Zayıflama amacıyla kullanılmaktadır & HÖ 1068 \\
\hline
\end{tabular}




\begin{tabular}{|c|c|c|c|c|c|}
\hline Poaceae & Zea mays L. & Misir & Püskülü & $\begin{array}{l}\text { Püskülü kaynatılarak idrar sökücü ve kumu } \\
\text { düşürmede kullanılmaktadır. Ayrıca zayıflama } \\
\text { amaçlı yapılan terkiplere katılmaktadır }\end{array}$ & HÖ 1054 \\
\hline Portulacaceae & Portulaca oleracea L. & $\begin{array}{l}\text { Semizotu, } \\
\text { Parpar }\end{array}$ & Toprak üstü kısım & $\begin{array}{l}\text { Kolesterolün düşürülmesinde ve kan basıncının } \\
\text { dengelenmesinde kullanılmaktadır }\end{array}$ & HÖ 1073 \\
\hline Ranunculaceae & Nigella sativa L. & $\begin{array}{l}\text { Çörekotu, Kara } \\
\text { çörek }\end{array}$ & $\begin{array}{l}\text { Tohumları } \\
\text { Sabit yağ }\end{array}$ & $\begin{array}{l}\text { Tohumlardan elde edilen yağ haricen saç } \\
\text { dökülmesi ve kepeğe karşı kullanılmaktadır. } \\
\text { Ayrıca bağışıklık sistemini güçlendirici amaçlar } \\
\text { için de yenilmektedir }\end{array}$ & HÖ 1024 \\
\hline Rhamnaceae & Frangula alnus Mill. & Acı çehre & Kuru meyve & $\begin{array}{l}\text { Zayıflamada, yağların azalmasında, ödemin } \\
\text { atılmasında, kan sekeri ve kolesterolün } \\
\text { düzenlenmesinde kullanılmaktadır }\end{array}$ & HÖ 1104 \\
\hline Rhamnaceae & Ziziphus jujuba Mill. & Hünnap & $\begin{array}{l}\text { Yaprak, meyve, sabit yağ, kuru } \\
\text { meyve, tentür }\end{array}$ & $\begin{array}{l}\text { Balgam yumuşatıcı, idrar söktürücü ve kolesterol } \\
\text { düşürücü olarak kullanılmaktadır }\end{array}$ & HÖ 1063 \\
\hline Rosaceae & Alchemilla vulgaris $\mathrm{L}$. & Aslanpençesi & Toprak üstü kısımlar & $\begin{array}{l}\text { Bayanlarda tüylenmeye karşı, Östrojen hormonu } \\
\text { yükseltici, adet düzensizliğine karşı yardımcı ve } \\
\text { destekleyici olarak kullanılmaktadır }\end{array}$ & HÖ 1078 \\
\hline Rosaceae & $\begin{array}{l}\text { Cerasus mahaleb (L.) Mill. var. } \\
\text { mahaleb }\end{array}$ & Mahlep & Meyveleri & $\begin{array}{l}\text { Kuvvet verici, cinsel gücü artırıcı ve prostat } \\
\text { büyümesini önleyici } \\
\text { kullanılmaktadır }\end{array}$ & HÖ 1088 \\
\hline Rosaceae & $\begin{array}{l}\text { Crataegus monogyna Jacq. subsp. } \\
\text { monogyna }\end{array}$ & Alıç, Guviç & $\begin{array}{l}\text { Çiçek } \\
\text { Meyve } \\
\text { Yaprak }\end{array}$ & $\begin{array}{l}\text { İdrar artırıcı, yatıştırıcı, spazmları önleyici ve } \\
\text { tansiyon düşürücü olarak kullanılmaktadır }\end{array}$ & HÖ 1042 \\
\hline Rosaceae & Cydonia oblonga Mill. & Ayva yaprağ & Yaprak & $\begin{array}{l}\text { Bronşit, grip, nezle ve soğuk algınlığına karşı } \\
\text { kullanılmaktadır }\end{array}$ & HÖ 1129 \\
\hline Rosaceae & Prunus armeniaca L. & Kayısı & $\begin{array}{l}\text { Meyve } \\
\text { Çekirdek }\end{array}$ & $\begin{array}{l}\text { Meyvesi ve bitki çayı zayıflama } \\
\text { kullanılmaktadır }\end{array}$ & HÖ 1132 \\
\hline Rosaceae & $\begin{array}{l}\text { Prunus domestica L. } \\
\text { insititia (L.) C.K.Schneid. }\end{array}$ & Mürdüm eriği & Meyve & $\begin{array}{l}\text { Bağışılklık sistemi ve vücut } \\
\text { kuvvetlenmesinde kullanılmaktadır }\end{array}$ & HÖ 1135 \\
\hline Rosaceae & Prunus dulcis (Mill.) D.A. Webb & Acı badem & Tohum & $\begin{array}{l}\text { Şeker hastalığı ve kurt düşürücü durumlar için } \\
\text { kullanılmaktadır }\end{array}$ & HÖ 1022 \\
\hline Rosaceae & Prunus dulcis (Mill.) D.A. Webb & Tatlı badem & Bitkisel yağ & $\begin{array}{l}\text { Saç ve kirpiklerin dökülmesini önlemek amaçlı } \\
\text { kullanılmaktadır }\end{array}$ & HÖ 1121 \\
\hline Rosaceae & Rosa canina $\mathrm{L}$. & Kuşburnu & Meyvesi & $\begin{array}{l}\text { Idrar artırıcı, kuvvet verici ve zayıflamak amaçlı } \\
\text { kullanılmaktadır }\end{array}$ & HÖ 1113 \\
\hline Rosaceae & Rosa spp. & Gül & Petalleri & $\begin{array}{l}\text { Çocukların sancılarını durdurmak amaçlı } \\
\text { kullanılmaktadır }\end{array}$ & HÖ 1051 \\
\hline Rosaceae & Rubus canescens DC. & Böğürtlen & Kökü & Şeker hastalığında kullanılmaktadır & HÖ 1052 \\
\hline Rubiaceae & Galium verum L. subsp. verum & Sarı yoğurt otu & Çiçekli gövde uçları & $\begin{array}{l}\text { Guatr hastalığı ve kan yapıcı amaçlar için } \\
\text { kullanılmaktadır }\end{array}$ & HÖ 1019 \\
\hline Rutaceae & Ruta chalepensis L. & Sedef otu & Toprak üstü kısımları & $\begin{array}{l}\text { Tansiyon ve dolaşım bozukluklarında ve haricen } \\
\text { de romatizmaya karşı kullanılmaktadır }\end{array}$ & HÖ 1069 \\
\hline
\end{tabular}




\begin{tabular}{|c|c|c|c|c|c|}
\hline Santalaceae & Viscum album L. subsp. album & Ökseotu, Çekem & Meyveleri & $\begin{array}{llr}\begin{array}{l}\text { Kusturucu, tansiyon düşürücü, } \\
\text { kuvvetlendirici, }\end{array} \text { yatıştırıcı } & \text { olarak } \\
\text { kullanılmaktadır } & & \end{array}$ & HÖ 1096 \\
\hline Sapotaceae & Argania spinosa (L.) Skeels & Argan & Uçucu yă̆ & $\begin{array}{l}\text { Cilt parlaklığını artırmada ve saç dökülmesini } \\
\text { engellemeye karşı kullanılmaktadır }\end{array}$ & HÖ 1137 \\
\hline Sapindaceae & Aesculus hippocastanum L. & Atkestanesi & Meyvesi & $\begin{array}{l}\text { Damar daraltıcı, kan kesici, ateş düşürücü, basur } \\
\text { memelerini küçültücü amaçlar için } \\
\text { kullanılmaktadır }\end{array}$ & HÖ 1039 \\
\hline Scrophulariaceae & Verbascum tenue Murb & Sığırkuyruğu & Çiçekleri & $\begin{array}{l}\text { Astım rahatsızlı̆̆ında ve balgam sökücü olarak } \\
\text { kullanılmaktadır. }\end{array}$ & HÖ 1046 \\
\hline Simaroubaceae & Quassia amara L. & Acı Yonga & Kabuk & $\begin{array}{l}\text { iştah açıcı, kuvvet verici, metabolizmayı } \\
\text { güçlendirici ve bağırsaktaki kurtları düşürücü } \\
\text { amaçlar için kullanılmaktadır }\end{array}$ & HÖ 1100 \\
\hline Solanaceae & Hyoscyamus niger L. & $\begin{array}{l}\text { Kuşkana, } \\
\text { Durana }\end{array}$ & Meyveleri & Kansızlıkta kullanılmaktadır & HÖ 1114 \\
\hline Theaceae & Camellia sinensis ( L. ) Kuntze & Yeşil Çay & Yaprak & $\begin{array}{l}\text { Zayıflatıcı, kan şekeri düzenleyici ve kolesterol } \\
\text { dengeleyici amaçlar için kullanılmaktadır }\end{array}$ & HÖ 1017 \\
\hline Urticaceae & Urtica dioica $\mathrm{L}$. & Isırgan otu & $\begin{array}{l}\text { Tohumları } \\
\text { Kuru yaprakları }\end{array}$ & $\begin{array}{l}\text { Ağrı kesici, kan temizleyici, hormon dengeleyici, } \\
\text { cinsel gücü artırıcı ve kanser tedavisi için } \\
\text { kullanılmaktadır }\end{array}$ & HÖ 1115 \\
\hline Vitaceae & Vitis vinifera $L$. & Üzüm & Çekirdek, meyve & $\begin{array}{l}\text { Beden ve zihin gücü } \\
\text { kuvvetlendirici ve } \\
\text { kullanılmaktadır }\end{array}$ & HÖ 1005 \\
\hline Xanthorrhoeaceae & Aloe vera (L.) Burm.f. & Sarısabır & Yaprak & $\begin{array}{l}\text { Cilt tahrişlerinde, derideki yaralarda, vücuttaki } \\
\text { iltihabı ve ödemi geçirmede kullanılmaktadır }\end{array}$ & HÖ 1102 \\
\hline Zingiberaceae & Alpinia officinarum Hance & Havlican & Rizom & $\begin{array}{l}\text { Soğuk algınlığı, nezle ve gripte iyileştirici ve } \\
\text { bağırsaktaki gazları giderici ve romatizmaya } \\
\text { karşı kullanılmaktadır }\end{array}$ & HÖ 1040 \\
\hline Zingiberaceae & Curcuma longa L. & Zerdeçal & Kök & $\begin{array}{l}\text { İtihap giderici, sinirleri uyarıcı ve karaciğer } \\
\text { hastalıklarına karşı kullanılmaktadır }\end{array}$ & HÖ 1143 \\
\hline Zingiberaceae & Elettaria cardamomum (L.) Maton & Kakule & Meyve & $\begin{array}{l}\text { Böbrek hastalıklarında, mide hastalıklarında ve } \\
\text { solunum yolu hastalıklarında kullanılmaktadır }\end{array}$ & HÖ 1144 \\
\hline Zingiberaceae & Zingiber officinale Roscoe & Zencefil & Uçucu yağ, toprakaltı gövdesi & $\begin{array}{l}\text { Bronşite bağlı öksürükte ve iltihap kurutucu } \\
\text { olarak }\end{array}$ & HÖ 1035 \\
\hline Zygophyllaceae & Tribulus terrestis L. & $\begin{array}{l}\text { Çoban çökerten, } \\
\text { Demirdikeni }\end{array}$ & Meyveleri & $\begin{array}{l}\text { Taş düşürücü, idrar söktürücü ve kuvvet verici } \\
\text { özellikle damar tıkanıklığı rahatsızlıklarında } \\
\text { yaygın olarak kullanılmaktadır. }\end{array}$ & HÖ 1015 \\
\hline
\end{tabular}


Table 2. Compositions and other products sold in pharmacies and herbalists of Şanliurfa

\begin{tabular}{|c|c|c|c|}
\hline Ürünün Adı (Name of the Product) & $\begin{array}{l}\text { Üretici Firma } \\
\text { Manufacturer }\end{array}$ & Muhteviyatı (content) & Kullanım Amaçları (Intended Use) \\
\hline Kimyonlu rezene çayı & $\begin{array}{l}\text { Humana } \\
\text { Hekimhan } \\
\text { Mecitefendi }\end{array}$ & $\begin{array}{l}\text { Cumium cyminum L. } \\
\text { Foeniculum vulgare Mill. }\end{array}$ & $\begin{array}{l}\text { Anne sütü arttırıcı, bebeklerde gaza bağlı olarak mide ve } \\
\text { bağırsak sistemindeki gaz sancılarının giderilmesi }\end{array}$ \\
\hline Papatya çayı & $\begin{array}{l}\text { Milupa } \\
\text { Mecitefendi } \\
\text { Nurs }\end{array}$ & Matricaria chamomilla L. & Sakinleştirici ve mideyi rahatlatıcı \\
\hline Mate & Fitovision & Ilex paraguariensis A.St.-Hil. & Zayıflama çayı, sakinleştirici \\
\hline Fito- L & Fitovision & $\begin{array}{l}\text { Hibiscus sabdariffa L. } \\
\text { llex paraguariensis St. Hill. } \\
\text { Prunus domestica L. subsp. insititia (L.) C.K. } \\
\text { Schneid. } \\
\text { Prunus avium L. } \\
\text { Camellia sinensis (L.) Kuntze } \\
\text { Frangula purshiana L. } \\
\text { Calluna vulgaris L. Hull. }\end{array}$ & Zayıflama çayı \\
\hline Fito-relax & Fitovision & $\begin{array}{l}\text { Melissa officinalis L. } \\
\text { Lavandula angustifolia Mill. } \\
\text { Passiflora edulis Sims. } \\
\text { Humulus lupulus L. }\end{array}$ & Rahatlatıcı, strese karşı \\
\hline Ballı harnuplu bitkisel çay & Themra bitkisel ürünler & Ceratonia siliqua L. & Cinsel güç arttırıcı, kısırlık tedavisinde \\
\hline Ballı kırmızı ginsengli macun & Themra bitkisel ürünler & Panax ginseng C.A. Meyer. & Cinsel yetersizliğe karşı, güçsüzlük ve strese karşı \\
\hline $\begin{array}{l}\text { Harnuplu ve Polenli bitkisel karışım } \\
\text { macun }\end{array}$ & Çinar & Ceratonia siliqua L. & Cinsel güç arttırıcı, kısırlık tedavisinde \\
\hline $\begin{array}{l}\text { Keçiboynuzu özü ve vitamin içeren takviye } \\
\text { edici gida }\end{array}$ & Hünnap & Ceratonia siliqua L. & Cinsel güç arttırıcı, kısırlık tedavisinde \\
\hline Üzüm çekirdeği ekstresi şurubu & Nutrigen & Vitis viniferae $\mathrm{L}$. & Çocukların gelişimine yardımcı \\
\hline Meyan balı Bitkisel pastil & Otacl & Glycyrrhiza glabra L. & Balgam söktürücü, boğaz iltihabı azaltıcı \\
\hline Ginseng içeren takviye edici gıda & Pharmaton & Panax ginseng C.A. Meyer. & Enerji verici \\
\hline Passiflora şurup & Sandoz & Passiflora edulis Sims. & $\begin{array}{l}\text { Huzursuzluk, endişe, ruhsal sıkıntıların giderilmesinde ve } \\
\text { uykusuzluk tedavisinde }\end{array}$ \\
\hline $\begin{array}{l}\text { Yer fistığı yağı içeren takviye edici gıda } \\
\text { (kapsül ve şurup) }\end{array}$ & Zade vital & Arachis hypogaea L. & Kolestrol düzenleyici, bağışıklığı güçlendirici \\
\hline Melissa liquid (damla ve şurup) & $\begin{array}{l}\text { BayBay } \\
\text { Infanium }\end{array}$ & Melissa officinalis L. & Bebeklerde rahatlatıcı ve uykuya yardımcı \\
\hline Sistifix & Zade vital & $\begin{array}{l}\text { Vaccinium macrocarpon L. } \\
\text { Salvia officinalis L. }\end{array}$ & İdrar yolları enfeksiyonları, Bağışıklığı güçlendirici \\
\hline Çörek otu yağı içeren takviye edici gıda & Zade vital & Nigella sativa L. & Cilt güzelliği, kabızlık, mide ağrıları, bağırsak kurtları \\
\hline
\end{tabular}




\begin{tabular}{|c|c|c|c|}
\hline $\begin{array}{l}\text { Tusimed (kekik, hatmi, zencefil, aserola, } \\
\text { meyan kökü) }\end{array}$ & Medicago & $\begin{array}{l}\text { Thymus fallax Fisch \& C.A. Meyer. } \\
\text { Althaea officinalis L. } \\
\text { Zingiber officinale Roscoe } \\
\text { Malpighia emarginata D.C. } \\
\text { Glycyrrhiza glabra L. }\end{array}$ & Bağışıklığı güçlendirmek için \\
\hline Ivy leaves dry extract cough syrup & Prospan & Hedera helix L. & Öksürük şurubu \\
\hline Kara mürver extresi kapsülü & Zade vital & Sambucus nigra L. & $\begin{array}{l}\text { Grip, neze ve soğuk algınlığına karşı, bağışıklığı } \\
\text { güçllendirici }\end{array}$ \\
\hline Karadut şurubu & Ress & Morus nigra L. & Aft, mantar ve ağız içi yaralarının iyileştirilmesinde \\
\hline Curcumin (Kapsül) & $\begin{array}{l}\text { Solgar } \\
\text { Zade Vital }\end{array}$ & Curcuma longa $\mathrm{L}$. & $\begin{array}{l}\text { İltihaplanmayı azaltmaya, osteoartrit ve romatoid artrit, } \\
\text { ağrı ve inflamasyon semptomlarını hafifletmeye yardımcı }\end{array}$ \\
\hline Chia tohumu tıbbi bitkisel drog & Fitovision & Salvia hispanica L. & Hafıza güçlendirici, zayıflama \\
\hline Hayıt tohumu tıbbi bitkisel drog & Fitovision & Vitex agnus-castus L. & Kadınsal hormonları düzenleyici, anne sütü arttırıcı \\
\hline Yeşil çay tıbbi bitkisel drog & Fitovision & Camellia sinensis (L.) Kuntze & Zayıflatıcı, dolaşım sistemini koruyucu \\
\hline Keten tohumu tıbbi bitkisel drog & Fitovision & Limum usitatissimum L. & Zayıflatıc1 \\
\hline Moringa tıbbi bitkisel drog & Fitovision & Moringa oleifera Lam & Zayıflatıcı \\
\hline Çoban çökerten bitkisel drog & Fito viston & Tribulus terrestris L. & Cinsel güç arttırıcı \\
\hline Beyaz çay & $\begin{array}{l}\text { Fito viston } \\
\text { Fitovision }\end{array}$ & Camellia sinensis (L.) Kuntze & Sakinleştirici, zayıflama, antioksidan özelliği \\
\hline fito-milk & fito viston & $\begin{array}{l}\text { Cuminum cyminum L. } \\
\text { Foeniculum vulgare Mil. } \\
\text { Melissa officinalis L. } \\
\text { Prunus domestica L. subsp. insititia (L.) C.K. } \\
\text { Schneid. }\end{array}$ & Anne sütü arttırıcı, bebek için gaz giderici \\
\hline Ginsengli karışık bitki çayı & $\begin{array}{l}\text { Nurs lokman hekim } \\
\text { mecitefendi }\end{array}$ & Panax ginseng C.A Meyer. & Yorgunluk, güçsüzlük ve strese karşı \\
\hline Zencefilli karışık bitki çayı & $\begin{array}{l}\text { Nurs } \\
\text { Doğadan } \\
\text { Shiffa home }\end{array}$ & Zingiber officinale Roscoe & Öksürük ve iltihap kurutucu \\
\hline Bodurotlu karışık bitki çayı & Nurs lokman hekim & Teucrium polium L. & Sakineştirici, konsantrasyon bozukluğuna karşı \\
\hline Acı çehreli karışık bitki çayı & Nurs & Frangula alnus Mill. & Sindirim sistemine yardımcı ve Zayıflama \\
\hline Isırgan bitki çayı & $\begin{array}{l}\text { Nurs } \\
\text { Sema sultan } \\
\text { Prof saraçoğlu }\end{array}$ & Urtica dioica $\mathrm{L}$. & $\begin{array}{l}\text { stresi azaltan, kan basıncını, kan şekerini, kolestrolü } \\
\text { düzenleyen, ağrı ve iltihabı hafifleten }\end{array}$ \\
\hline Sinameki bitki çayı & $\begin{array}{l}\text { Nurs } \\
\text { Arifoğlu }\end{array}$ & Senna marilandica (L.) Link & Zayıflama çayı, kabızlık giderici \\
\hline Adaçayı bitki çayı & $\begin{array}{l}\text { Nurs } \\
\text { Prof saraçoğlu }\end{array}$ & Salvia fruticosa Mill. & Bağışıklığı güçlenderici, zihin açıcı, depresyona karşı \\
\hline Karabaş otu bitki çayı & Nurs & Lavandula stoechas L. & Bağışıklığı güçlendirici, bağırsak gazlarını giderici \\
\hline Kuşburnu bitkisel çay & $\begin{array}{l}\text { Nurs } \\
\text { Doğadan }\end{array}$ & Rosa canina L. & Bağışıklık sistemini güçlendirici \\
\hline
\end{tabular}




\begin{tabular}{|c|c|c|c|}
\hline Ebe gümeci bitki çayı & $\begin{array}{l}\text { Nurs } \\
\text { Themra }\end{array}$ & Malva sylvestris L. & $\begin{array}{l}\text { Solunum yolu hastalıklarında (balgam söktürücü, bronşit, } \\
\text { öksürük, anfizem) }\end{array}$ \\
\hline Çakşır otu kökü bitki çayı & Nurs & Ferula orientalis L. & Cinsel gücü artırıcı ve kısırlığı önleyici \\
\hline Ekinezya bitki çayı & $\begin{array}{l}\text { Nurs } \\
\text { Doğadan } \\
\text { Doğuş }\end{array}$ & Echinacea purpurea L. & soğuk algınlığı, grip, sinüzit, faranjit, boğaz iltihabına karşı \\
\hline Yakı otlu bitki çayı & Mecitefendi & Epilobium angustifolium L. & Prostat tedavisinde \\
\hline Avokado yapraklı çay & Mecitefendi & Persea americana Mill. & Ağrı kesici, böbrek taşlarını düşürücü \\
\hline Zeytin yapraklı karışık bitki çayı & Nurs lokman hekim & Olea europaea L. & Bağışıklık sistmini güçlendirici \\
\hline Apitera mind & Balparmak & $\begin{array}{l}\text { Ginkgo biloba L. } \\
\text { Curcuma longa L. } \\
\text { Rosmarinus officinalis L. } \\
\text { Vaccinum myrtillus L. }\end{array}$ & $\begin{array}{l}\text { Bağışılklık sistemini güçlendirici, yorgunluğa ve halsizliğe } \\
\text { karşı }\end{array}$ \\
\hline Civanperçemi bitki çayı & Fito viston & Achillea millefolium D.C & Ağrı kesici sakinleştici \\
\hline Anasonlu karışık bitki çayı & $\begin{array}{l}\text { Ress } \\
\text { Dermolife }\end{array}$ & Pimpinella anisum L. & Anne sütünü arttırıcı \\
\hline Kayısılı biberiyeli bitki çayı & $\begin{array}{l}\text { Çınar } \\
\text { Esila } \\
\text { Akzer }\end{array}$ & $\begin{array}{l}\text { Prunus armeniaca L. } \\
\text { Rosmarinus officinalis L. }\end{array}$ & Zayiflama \\
\hline Teff tohumlu çay & Teaherb & Eragrostis tef (Zucc.) Trotter & Zayiflama \\
\hline $\begin{array}{l}\text { Passiflora ve Velerian Ekstratlı Takviye } \\
\text { Edici Gıda }\end{array}$ & Passifmood & $\begin{array}{l}\text { Passiflora edulis Sims. } \\
\text { Valeriana officinalis L. }\end{array}$ & Rahatlatıcı, strese karşı \\
\hline $\begin{array}{l}\text { Gasodex şurup (rezene, kimyon, anason, } \\
\text { papatya) }\end{array}$ & Nutrigen & $\begin{array}{l}\text { Foeniculum vulgare Mill. } \\
\text { Cuminum cyminum L. } \\
\text { Pimpinella anisum L. } \\
\text { Matricaria chamomilla L. }\end{array}$ & Bebek gazlarını çıkarmak amacıyla \\
\hline Vicol Bitkisel damla & Vicol Vitamax & $\begin{array}{l}\text { Matricaria chamomilla L. } \\
\text { Melissa officinalis L. } \\
\text { Cuminum cymimum L. } \\
\text { Anethum graveolens L. }\end{array}$ & Bebek gazlarını çıkarmak amacıyla \\
\hline Passiflora takviye edici gıda & $\begin{array}{l}\text { Passif Mood } \\
\text { Miraderm }\end{array}$ & Passiflora edulis Sims. & Rahatlatıcı, strese karşı \\
\hline zinco damla (kimyon yağı, dereotu yağ $)$ & Berko & $\begin{array}{l}\text { Cuminum cymimum L. } \\
\text { Anethum graveolens L. }\end{array}$ & Bebeklerde iştah açıcı, gelişime yardımcı \\
\hline Kudret narlı karışık bitkisel macun & $\begin{array}{l}\text { Hekimhan } \\
\text { Nurs }\end{array}$ & Momordica charantia L. & Mide ve bağırsak hastalıklarında \\
\hline Avokado yapraklı karışık bitkisel macun & Nurs & Persea americana L. & Böbrek taşlarının düşürmek için \\
\hline Biberiyeli karışık bitkisel macun & Nurs & Rosmarinus officinalis L. & Solunum yolları hastalıkları, zayıflama \\
\hline Çakşır kökü suyu & Mecitefendi & Ferula orientalis L. & Cinsel gücü artırıcı ve kısırlığı önleyici \\
\hline Kekik suyu & Mecitefendi & Thymus falax Fisch \& C.A Meyer. & Görme yeteneğini artırmaya \\
\hline $\begin{array}{l}\text { Üzerlik tohumu bitkisel karışım toz ve } \\
\text { bitki çayı }\end{array}$ & $\begin{array}{l}\text { Themra } \\
\text { Mecitefendi }\end{array}$ & Peganum harmala L. & Soğuk algınlığında \\
\hline
\end{tabular}




\begin{tabular}{|c|c|c|c|}
\hline Ginkgo bilobalı bitkisel macun & Hekimhan & Ginkgo biloba L. & Astım, bronşit ve ruhsal rahatlama \\
\hline Aloe vera yağ, jel ve kremi & $\begin{array}{l}\text { Biorlx } \\
\text { Ddf } \\
\text { Babe } \\
\text { Badger }\end{array}$ & Aloa vera (L.) Burm.f. & Cilt güzelliği \\
\hline Doğal sarımsak özlü şampuan & $\begin{array}{l}\text { Fiyto } \\
\text { bioxcin } \\
\text { Zigavus } \\
\text { Natur way } \\
\text { Katrandükkanı } \\
\text { Naturaline } \\
\end{array}$ & Allium sativum L. & Saç dökülmesi \\
\hline Kinoa bitkisel toz ve bitki çayı & Nurs & Chenopodium quinoa Willd. & Zayıflama \\
\hline Isırgan tohumu yağı & $\begin{array}{l}\text { Zade vital } \\
\text { Talya }\end{array}$ & Urticae piluliferae L. & Cildin yenilenmesi ve canlanması, Saç dökülmesi \\
\hline Kayısı çekirdeği yağı & Botalife, Talya & Prunus armeniaca L. & Cilt nemlendirici \\
\hline Avokado yağı & Talya & Persea gratissima L. & Cilt güzelliği \\
\hline Hindistan cevizi yağı & Botalife & Cocos nucifera L. & Makyaj temizleyici \\
\hline Argan yağ & Botalife, mecitefendi & Argania spinosa (L.) Skeels & Saç dökülmesi \\
\hline Sarı kantaron yağı & $\begin{array}{l}\text { Botalife } \\
\text { Alvin }\end{array}$ & $\begin{array}{l}\text { Hypericum perforatum L. subsp. veronense } \\
\text { (Schrank) H. Linb. }\end{array}$ & Depresyona karşı \\
\hline Susam yağ̀ & Talya & Sesamum indicum L. & Kuvvet verici, Cilt güzelliği \\
\hline Çörek otu yağı & $\begin{array}{l}\text { Botalife, } \\
\text { Ress, zadevital }\end{array}$ & Nigella sativa L. & $\begin{array}{l}\text { Cilt güzelliği, kas ağrıları, baş ağrıları gibi dayanılmaz } \\
\text { ağrıları masaj yaparak gidermekte }\end{array}$ \\
\hline Kakao yağı & Botalife & Theobroma cacao L. & Dudak çatlakları, egzama ve sedef yaraları \\
\hline Kekik yağ & Talya, Leafy & Thymus fallax Fisch C.A. Meyer. & Öksürük, bronşit, soğuk algınlı̆ğ \\
\hline Çay ağacı yağı & Botalife & Melaleuca alternifolia James Cook & Akne ve sivilceye karşı, cilt sağlığı için \\
\hline Ardıç Tohumu Yağı & Botalife & Juniperus communis L. & İdrar yolları ve sindirim yolları hastalıkları için \\
\hline Çam terebentin yağ & Botalife & Pinus brutia Ten. & Cilt güzelliği, Saç dökülmesi \\
\hline Adaçayı yağı & Ress & Salvia fruticosa Mill. & Bağışıklığı güçlendirici, zihin açıcı \\
\hline Nar çekirdeği yağı & Botalife, Zade vital & Punica granata L. & Cilt güzelliği için \\
\hline Rezene yağ 1 & Botalife & Foeniculum vulgare L. & Anne sütü arttırıcı \\
\hline Tatlı Badem yağı & $\begin{array}{l}\text { Miraderm } \\
\text { Mecitefendi }\end{array}$ & Prunus dulcis (Mill.)D.A.Webb & Cildi güzelleştirir, kirpik dökülmesini önler. \\
\hline Acı badem yağı & Alvin, Arifoğlu & Amygdalus communis L. & Cilt güzelliği, Saç besleyici \\
\hline Ylang ylang yağı & Alvin & Cananga odorata (Lam.) Hook.f. \& Thomson & Afrodizyak, uykusuzluk problemi, sakinleştici \\
\hline
\end{tabular}


Çizelge 3. Araştırmanın diğer çalışmalarla karşılaştırılması

Table 3. Comparison of our research with other studies

\begin{tabular}{|c|c|c|c|c|}
\hline $\begin{array}{l}\text { Çalışmanın sonuçları } \\
\text { Results of the study }\end{array}$ & $\begin{array}{l}\text { Bu çalışma } \\
\text { Present } \\
\text { study }\end{array}$ & $\begin{array}{l}\text { Gaziantep ili } \\
\text { aktarlarında } \\
\text { satılan bitkiler ve } \\
\text { Etnobotanik } \\
\text { özellikleri (Yiğit, } \\
\text { 2014) }\end{array}$ & $\begin{array}{l}\text { Kahramanmaraş } \\
\text { şehir merkezindeki } \\
\text { aktarlarda bulunan } \\
\text { tıbbi bitkiler } \\
\text { (Çömlekçioğlu ve } \\
\text { Karaman, 2008) }\end{array}$ & $\begin{array}{lr}\text { Adana } & \text { Aktarlarında } \\
\text { tedavi } & \text { amacıyla } \\
\text { satılan } & \text { bitkisel } \\
\text { droglar } & \text { (Kayıran ve } \\
\text { Kırıcı, 2019) }\end{array}$ \\
\hline $\begin{array}{l}\text { Familya sayısı } \\
\text { Family number }\end{array}$ & 70 & - & - & - \\
\hline $\begin{array}{l}\text { Takson sayısı } \\
\text { Number of taxa }\end{array}$ & 144 & 122 & 178 & 142 \\
\hline $\begin{array}{l}\text { Terkip sayısı } \\
\text { Number of preparations }\end{array}$ & 84 & & - & - \\
\hline $\begin{array}{l}\text { Kaynak kişi sayısı } \\
\text { Number of resource } \\
\text { persons }\end{array}$ & 61 & 30 & 17 & 20 \\
\hline
\end{tabular}

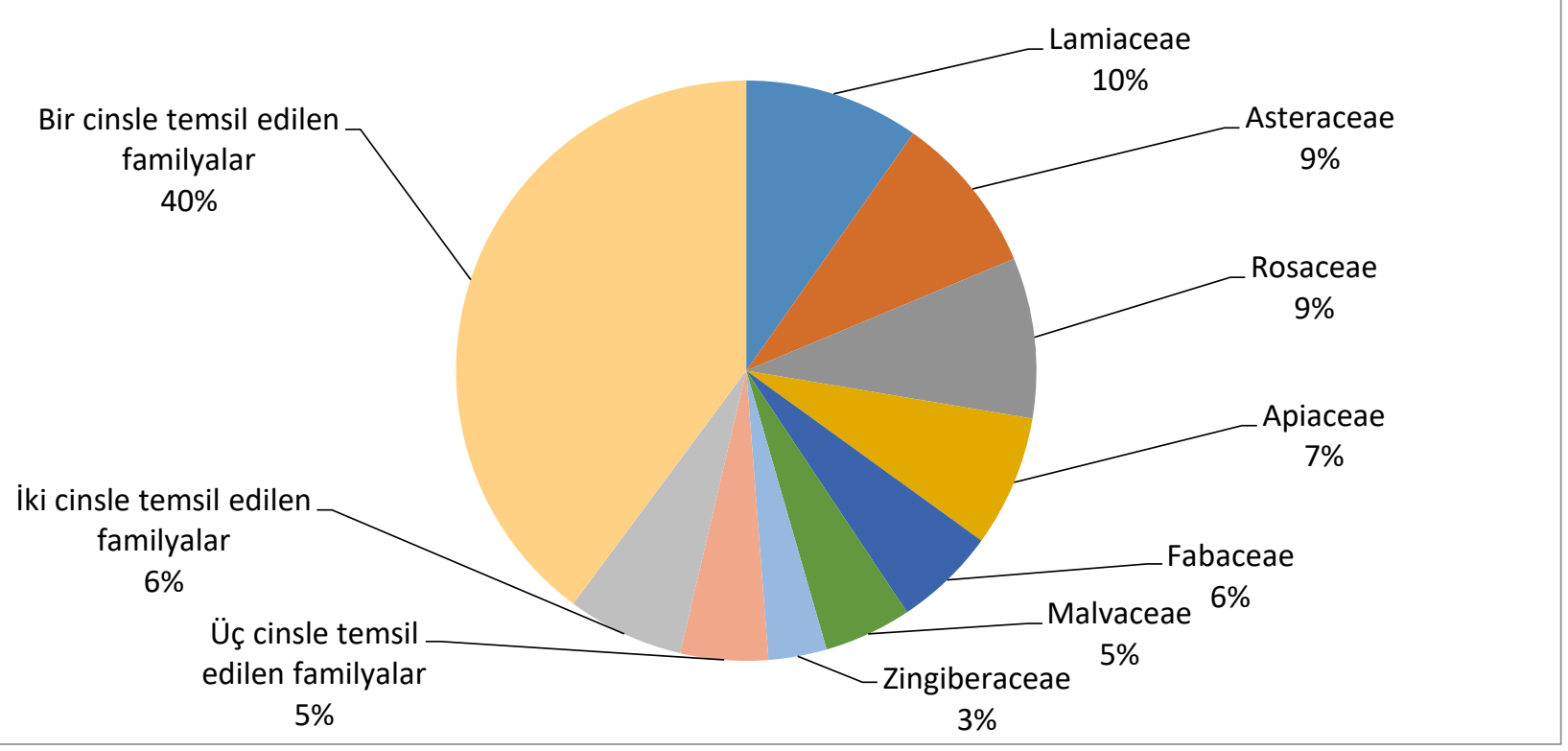

Şekil 2. Familyaların takson sayılarının yüzdelik dağılımı

Figure 2. Percentage distribution of taxa numbers of families

- Zayıflama amaçlı satılan bazı bitkiler; Ilex paraguairensis, Chenopodium quinoa, Juniperus communis, Juniperus oxycedrus, Salvia hispanica, Linum usitatissimum, Moringa oleifera, Eragrostis tef, Zea mays, Portulaca oleracea, Frangula alnus, Prunus armeniaca, Prunus armeniaca, Rosa canina, Camellia sinensis ve Tilia platyphyllos'drr.

- Bağışıklık sistemini güçlendirici amaçlı satılan bazı bitkiler; Anethum graveolens, Echinacea purpurea, Alkanna tinctoria, Arachis hypogaea, Malpighia emarginata, Hibiscus sabdariffa, Morus nigra, Olea europaea, Portulaca oleracea, Nigella sativa, Prunus domestica, Nigella sativa, Prunus domestica ve Rosa canina'dır.

- Afrodizyak amaçlı satılan bazı bitkiler Capparis sicula, Cananga odorata, Eryngium campestre, Ferula orientalis, Gundelia tournefortii, Terminalia citrina,
Ginkgo biloba, Cerasus mahaleb, Urtica dioica subsp. dioica ve Panax ginseng'dir.

- Saç dökülmesi, saç bakımı amaçlı satılan bitkiler; Allium sativum, Argania spinosa, Senna marilandica, Cocos nucifera, Juglans regia, Pinus brutia, Pistacia terebinthus, Platanus orientalis, Prunus dulcis, Punica granata, Lavandula angustifolia, Matricaria chamomilla, Momordica charantia ve Nigella sativa'dir.

- Soğuk algınlığını önleme amaçlı satılan bazı bitkiler; Alpinia officinarum, Curcuma longa, Cydonia oblonga, Echinacea purpurea, Gundelia tournefortii, Juniperus communis, Hibiscus sabdariffa Malpighia emarginata, Matricaria chamomilla, Mentha piperita, Peganum harmala, Rosmarinus officinalis, Sambucus nigra ve Thymus fallax'dir.

○ Ateş düşürücü amaçlı satılan bazı bitkiler; 
Aesculus hippocastanum, Alkanna tinctoria, Elaeagnus angustifolia, Hibiscus sabdariffa, Matricaria chamomilla, Quassia amara, Teucrium polium, Tilia platyphyllos ve Urtica dioica'dır.

- İshal kesici amaçlı satılan bazı bitkiler; Terminalia citrina, Ceratonia siliqua, Quercus infectoria, Hypericum perforatum ve Punica granatum'dir.

- Kabızlık giderici amaçlı satılan bazı bitkiler; Aloe vera, Alkanna tinctoria, Senna alexandrina, Senna marilandica, Capparis sicula, Cyperus rotundus, Senna marilandica, Lamium albüm, Laurus nobilis, Portulaca oleracea, Prunus armeniaca, Prunus domestica, Vitis vinifera ve Ziziphus jujuba'dır.

- Mevsimlere göre değişen drog satışlarına bakıldığında kış aylarında soğuk algınlığı, nezle, grip gibi rahatsızlıklara karşı kullanılan ve özellikle çay şeklinde tüketilen bitkilerin satışlarının arttığ belirlenmiştir. Kış aylarında satışı artan bitkiler Zahter (Thymbra spicata subsp. spicata), Ihlamur (Tilia platyphyllos subsp. platyphyllos), Zerdeçal (Curcuma longa), Zencefil (Zingiber officinale, Hatmi çiçeği (Althaea officinalis) ve Kuşburnu (Rosa canina) olarak sıralanabilir. Yaz aylarında ise acı cehre, deve gözü, sinameki, mısır püskülü ve kiraz sapı gibi sindirim sistemi rahatsızlıkları ve zayıflamaya yönelik bitkilerin satışının arttığı belirlenmiştir. Ayrıca Şanlıurfa'da oldukça yaygın olarak serinletici bir içecek olarak kullanılan meyan kökünden elde edilen şerbetin satışında da yaz aylarında ve ramazan ayında arttığı görülmüştür.

- Bazı aktar dükkânlarında, özellikle Haşimiye meydanı denilen Tenekeci aktar pazarında zirai ilaçların satıldığı tespit edilmiştir. Gezilen tüm aktarlar arasında \%7 oranına tekabül etmektedir. Gerekli merciler tarafından gerekli denetimlerin yapılması önerilmektedir.

- Aktarların sattıkları bazı terkiplerin veya macunların üzerinde içeriği belirtecek tarzda herhangi bir etikete yer verilmediği görülmüştür. Bu durumun, gerekli merciler tarafindan kontrol edilmesi önerilmektedir.

\section{TEŞEKKÜR}

Bilgilerine başvurduğumuz Şanlıurfa'daki Eczane sahipleri, aktarlara ve maddi destek sağlayan HÜBAK' a (Proje No 18103) teşekkür ederiz.

\section{Araştırmacıların Katkı Oranı Beyan Özeti}

Yazarlar makaleye eşit oranda katkı sağlamışlardır.

\section{Çıkar Çatışması Beyanı}

Makale yazarları aralarında herhangi bir çıkar çatışması yoktur.

\section{KAYNAKLAR}

Açıkgöz MA, Batı E, Demirkol G 2012. Bitkisel Tedavi, Halk Hekimliği ve Aktarlar. Tıbbı ve Aromatik
Bitkiler Sempozyumu Bildiri Özet Kitabı 458-461, 13-15 Eylül 2012, Tokat.

Adıgüzel F, Kızılaslan N 2016. İstanbul İlinde Tıbbi Aromatik ve Baharat Bitkileri Satışı Yapan Aktarların Yapisal Özellikleri ve Mevzuat Hakkındaki Görüşleri. Anadolu Tarım Bilimleri Dergisi 31(1): 40-59.

Akan H, Aslan M 2005. A Folkloric and Ethnobotanical Research on Sanliurfa Isot. IVth International Congress of Ethnobotany ICEB 2005, 21-26 August 2005, İstanbul.

Akan H, Aydoğdu M, Korkut MM, Balos MM 2013. An Ethnobotanical Research of the Kalecik Mountain Area (Şanlıurfa, South-East Anatolia). Biological Diversity andConservation 6 (2):84-90.

Akan H, Ayaz H 2016. Gölpınar (S,anlıurfa-Türkiye) Mesire Yeri Florası ve Etrafindaki Kölerin Etnobotanik Özellikleri. Bağbahçe Bilim Dergisi 2(3):64-94

Akan H, Aslan M, Balos MM 2005. Sanliurfa Semt Pazarlarında Satılan Dogal Bitkilerin Etnobotanigi. Ot Sistematik Botanik Dergisi 12 (2):43-58.

Akan H, Aslan M, Eker İ 2004. Capparis L. (Kapari) Cinsinin GAP Bölgesindeki İşlenmesi, İhracatı ve Son Populasyon Durumu. Ot Sistematik Botanik Dergisi 11 (1):105-118.

Akan H, Bakır SY 2015. Kahta (Adıyaman) Merkezi ve Narince Köyünün Etnobotanik Açıdan Araştırılması. Bitlis Eren Üniversitesi Fen Bilimleri Dergisi 4(2):219-248

Akan H, Balos M 2008. GAP Bölgesi'nden Toplanan Meyan Kökü (Glycrrhiza glabra L.) Taksonunun İhracat Durumu, Etnobotanik Özellikleri ve Tibbi Önemi. Frrat Üniversitesi Fen ve Mühendislik Bilimleri Dergisi 20 (2): 233-241.

Akan H, Korkut MM, Balos MM 2008. Arat Dağ̀ ve Çevresinde (Birecik, Şanlıurfa) Etnobotanik Bir Araştırma. Frrat Üniversitesi Fen ve Mühendislik Bilimleri Dergisi 20 (1): 67-81).

Akan H, Balos MM, Tel AZ 2013. Birecik (Şanlıurfa) Yöresindeki Bazı Baklagil Bitkilerin Etnobotanik Özellikleri Adıyaman Üniversitesi Tarımsal Araştırma ve Uygulama Merkezi Uluslararası Dergisi 1 (1): 32-40.

Akman Y 2011. İklim ve Biyoiklim. Ankara: Palme Yayınları.

Akbulut S, Özkan ZC 2016. Herbalist-Customer Profile in Medicinal and Aromatic Herbs Trade: A Case Study of Kahramanmaras, Turkey. Kastamonu University Journal of Forestry Faculty 16 (1): 246-252

Alpınar K, Yazıcığlu E 2019. Türkiye Etnobotanik Bibliyografyası 1928-2018. Erol Ofset Matbaacılık, Samsun.

Altan S 2008. Aktarlar: Şifalı Bitkilerin Kullanımı ve Etik Sorunlar. Turkiye Klinikleri Journal of Medical Sciences 28 (6): 209-212. 
Altay V, Karahan F 2012. Tayfur Sökmen Kampüsü (Antakya-Hatay) ve Çevresinde Bulunan Bitkiler Üzerine Etnobotanik Bir Araştırma. Karadeniz Fen Bilimleri Dergisi 3(2):13-28.

Altay V, Karahan F, Sarcan YB, İlçim A 2015. An Ethnobotanical Research on Wild Plants Sold in Kirıkhan District (Hatay/Turkey) Herbalists and Local Markets. Biological Diversity and Conservation 8(2): 81-91.

Anonim 2010. İl Çevre Durum Raporu. Şanllurfa Valiliği Çevre ve Şehircilik İl Müdürlüğü, Şanlıurfa.

Anonim 2020a. Geleneksel ve Tamamlayıc Tip Uygulamalarının Klinik Araştırmaları Hakkında yönetmelik https://getatportal.saglik.gov.tr/

Anonim 2020b. The Plant List (2013). http://www.theplantlist.org/tpl1.1/search?q=carex (erişim tarihi: 28.02.2020).

Aslan M 2013. Plants Used for Medical Purposes in Şanlıurfa (Türkiye). Kahramanmaraş Sütçü İmam Üniversitesi Doğa Bilimleri Dergisi 16(4): 28-35.

Ayanoğlu, F., Mert, A., Kaya, D. A. 1999. Hatay Yöresinde Halk Arasında Kullanılan Bazı Önemli Tıbbi ve Kokulu Bitkilerin Toplanması. Mustafa Kemal Üniversitesi Ziraat Fakültesi Dergisi 4 (1-2): 101-116.

Aydoğdu M, Akan H 2005. The Flora of Kalecik Mountain (Sanllurfa, Turkey). Turkish Journal of Botany 29 (2): 55-174.

Balos MM, Akan H 2007. Zeytinbahçe-Akarçay (Birecik, Şanlıurfa) Arasında Kalan Bölgenin Etnobotanik Özellikleri. Selçuk Üniversitesi Fen Edebiyat Fakültesi Fen Dergisi 2(29):170: 155-171

Başaran AA 2012. Türkiyedeki Bitkisel İlaçlar ve Ürünlerde Yasal Durum. MISED (27-28):22-26.

Başer KHC, Honda G, Miki W 1986. Türkiye'de Aktarlar ve Bitkisel Droglar. İslam Kültürü Araştırmaları Serisi No:27.

Bayramoğlu MM, Toksoy D 2009. Aktarlar ve Tibbi Bitki Ticareti Üzerine Bir Araştırma (Doğu Karadeniz Bölgesi Örneği). Orman Mühendisliği Dergisi 45 (6): 34-39.

Baytop T 1984. Türkiye'de Bitkiler ile Tedavi. İstanbul Üniv. Yay. No. 3637, Eczacılık Fakültesi Yayın No.40: 240-376, İstanbul.

Bulut G, Korkmaz A, Tuzlacı E 2017. The Ethnobotanical Notes from Nizip (GaziantepTurkey). İstanbul Journal of Pharmacy 47(2): 5762.

Çini M 1983. Urfa'ya özgü ilaçlar. Şanlıurfa Harran Dergisi 19: 6-7.

Çömlekçioğlu N, Karaman Ş 2008. Kahramanmaraş Şehir Merkezindeki Aktar'larda Bulunan Tibbi Bitkiler. KSÜ Fen ve Mühendislik Dergisi 11(1):2332.

Çubukcu B, Sarıyar G, Meriçli AH, Sütlüpınar N, Mat A, Meriçli F 2002. Fitoterapi Yardımcı Ders Kitabı. İÜ Eczacılık Fakültesi Yayın No: 79, İstanbul:
İstanbul Üniversitesi Basım ve Yayınevi Müdürlüğü.

Davis PH 1965-1985. Flora of Turkey and the East Aegean Island. Edinburgh: Edinburgh Univ. Press., vol. 1-9.

Davis PH, Milli RR, Kit T 1988. Flora of Turkey and the East Aegean Island, 10 (Suppl. I). Edinburgh: Edinburgh Univ. Press.

Deniz L, Serteser A, Kargioğlu M 2010. Uşak Üniversitesi ve Yakın Çevresindeki Bazı Bitkilerin Mahalli Adları ve Etnobotanik Özellikleri. Afyon Kocatepe Üniversitesi Fen ve Mühendislik Bilimleri Dergisi 10 (1): 57-72.

Ersin F, Aksoy Ş 2004. Şanlıurfa'da Bir Halk Hekimi Attar İsa'. Türkiye Klinikleri Journal of Medical Ethics-Law and History 12(2): 87-91.

Ersöz T 2012. Bitkisel İlaçlar ve Gıda Takviyeleri ile İlgili Genel Yaklaşım ve Sorunlar. Mised (27-28): 919.

Demirez M, Nilufer O, Ergun F 2014. Ankara Aktarlarında Nane Adıyla Satılan Örnekler Üzerinde Çalışmalar. Spatula DD 4(4):223-231.

Faydaoğlu E, Sürücüoğlu MS 2011. Geçmişten Günümüze Tıbbi ve Aromatik Bitkilerin Kullanılması ve Ekonomik Önemi. Kastamonu Üniversitesi Orman Fakültesi Dergisi 11 (1):52-67.

Furkan MK 2016. Adıyaman İlinde Yetişen Bazı Bitkilerin Etnobotanik Özellikleri. Adıyaman Üniversitesi Fen Bilimleri Enstitüsü Yüksek Lisans Tezi, 20 sy.

Güner A, Aslan S, Ekim T, Vural M, Babaç MT 2012. Türkiye Bitkileri Listesi (Damarlı Bitkiler). İstanbul: Nezahat Gökyiğit Botanik Bahçesi ve Flora Araştırmalar Derneği Yayını 1, 1290 sy.

Heinrich M, Barnes J, Gibbons S, Williamson EM 2004. Fundementals of Pharmacognosy and Phytotherapy.Churchill Livingstone, Edinburgh.

Kaya ÖF, Dağlı M, Çelik HT 2019. An Ethnobotanical Research in Şanllurfa Central District and Attached Villages (Turkey). Indian Journal of Traditional Knowledge 19(1):7-23.

Kayıran SD, Kırıcı S 2019. Adana (Türkiye) Aktarlarında Tedavi Amacıyla Satılan Bitkisel Droglar. Kahramanmaraş Sütçü İmam Üniversitesi Tarım ve Doğa Dergisi 22(2):183-192.

Kendir G, Güvenç A 2010. Etnobotanik ve Türkiye'de Yapılmış Etnobotanik Çalışmalara Genel Bir Bakış. Hacettepe Üniversitesi Eczacılık Fakültesi Dergisi 30 (1):49-80.

Kırıcı S 2015. Türkiye'de Tıbbi ve Aromatik Bitkilerin Genel Durumu. Türktob, Türkiye Tohumcular Birliği Dergisi 15:4-11.

Koçtürk OM, Kalafatçılar ÖA, Özbilgin N, Atabay H 2009. Türkiye'de Bitkisel İlaçlara Bakış. Ege Üniversitesi Ziraat Fakültesi Dergisi 46 (3): 209214.

Korkmaz M, Karakurt E 2014. Kelkit (Gümüşhane) Aktarlarında Satılan Tıbbi Bitkiler. Journal of 
Natural \& Applied Sciences 18 (3):60-80.

Kökçü B, Esen O, Uysal E 2015. Medicinal Plants Sold in Çanakkale/Turkey City Center Herbalists. Biological Diversity and Conservation 8 (3): 80-91.

Leblebici S, Bahtiyar DS, Özyurt SM 2012. Kütahya Aktarlarında Satılan Bazı Tıbbi Bitkilerin Ağır Metal Miktarlarının İncelenmesi. Dumlupınar Üniversitesi Fen Bilimleri Enstitüsü Dergisi 29 (1): 1302-3055.

Malyer H, Aydın SÖ, Tümen G, Er S 2004. Tekirdağ ve Çevresindeki Aktarlarda Satılan Bazı Bitkiler ve Tıbbi Kullanım Özellikleri. Dumlupınar Üniversitesi Fen Bilimleri Enstitüsü Dergisi (007):103-11.

Özel A 1999. Güneydoğu Anadolu Bölgesi Tıbbi ve Aromatik Bitkileri. GAP I. Tarım Kongresi 26-28 Mayıs 1999, Şanlıurfa.

Özhatay E 2017. İstanbul'un Avrupa Yakasindaki Eczane ve Aktarlarında Zayıflatıcı Amaçlı Satılan Bitkisel Droglar. lectio scientific, 1(1): 18-25.

Polat R, Selvi S, Çakıllcıŏlu U, Açar M 2012. Investigations of Ethnobotanical Aspect of Wild Plants Sold in Bingöl (Turkey) Local Markets. Biological Diversity and Conservation 5 (3):155161.

Polat R, Çakılcıŏlu U, Ertuğ F, Satıl F 2012. An Evaluation of Ethnobotanical Studies in Eastern Anatolia. Biological Diversity and Conservation 5(2):23-40.

Saraçoğlu A, Ergün B 2006. Türkiye'de Satılan Bazı Bitkisel Zayıflama Çaylarının İçerikleri ve $\mathrm{Bu}$ Çayların Kullanımına Bağlı Ortaya Çıkabilecek İstenmeyen Etkiler. Türkiye Klinikleri J Med Sci $26: 355-363$

Sargin SA, Selvi S, Erdoğan E 2013. Alaşehir (Manisa) Yöresindeki Aktarlarda Satılan Tıbbi Bitkiler ve Kullanım Özellikleri. Biological Diversity and Conservation 6(3):4-45.

Sarışen O, Calışkan D 2005. Fitoterapi: Bitkilerle Tedaviye Dikkat. Sted 14(8): 182-87.

Saskara C, Hürkul MM, Güvenç A 2010. Morphological and Anatomical Studies on Melissa officinalis L. (Balm, Melissa) which Sold in
Herbalists. Ankara Üniversitesi Eczacıllk Fakültesi Dergisi 39 (2):123-143.

Selvi S, Dağdelen A, Kara S 2013. Kazdağlarından (Balıkesir-Edremit) Toplanan ve Çay olarak Tüketilen Tıbbi ve Aromatik Bitkiler. Tekirdağ Ziraat Fakültesi Dergisi 10(2): 26-33

Sıcak Y, Çolak ÖF, Ilhan V, Sevindik E, Alkan N 2013. Köyceğiz Yöresinde Halk Arasında Yaygın Olarak Kullanılan Bazı Tibbi ve Aromatik Bitkiler. Anadolu Doğa Bilimleri Dergisi 4(2): 70-77.

Solmaz E, Pınar AE 2009. Bitkilerle Tedavilerin Yan Etkileri. Türk Hijyen ve Deneysel Biyoloji Dergisi 66 (3):133-141.

Tulukcu E, Sağdıç O 2011. Konya'da Aktarlarda Satılan Tıbbi Bitkiler ve Kullanılan Kısımları. Erciyes Üniversitesi Fen Bilimleri Dergisi 27(4):304-308.

Uzun BM, Aykaç G, Özçelik G 2014. Bitkisel Ürünlerin Yanlış Kullanımı ve Zararları. Mersin Üniversitesi Tıp Fakültesi Lokman Hekim Tıp Tarihi ve Folklorik Tip Dergisi 4(3):1-5.

Volkan G, Dinler BS 2016. Kumru (Ordu) Yöresinde Doğal Olarak Yetişen Bazı Tıbbi ve Aromatik Bitkiler. SDÜ Ziraat Fakültesi Dergisi 11(1):146156.

Yapıcı İÜ, Hoşgören H, Saya Ö 2009. Kurtalan (Siirt) İlçesinin Etnobotanik Özellikleri. Dicle Üniversitesi Ziya Gökalp Eğitim Fakültesi Dergisi 12:191-196.

Yıldırımlı Ş 2004. Etnobotanik ve Türk Etnobotaniği. Kebikeç-İnsan Bilimleri İçin Kaynak Araştırmaları Dergisi 17:175-193.

Yiğit SS 2014. Gaziantep İli Aktarlarında Satılan Bitkiler ve Etnobotanik Özellikleri. Gaziantep Üniversitesi Fen Bilimleri Enstitüsü Biyoloji Anabilim Dalı Yüksek Lisans Tezi, 195 sy.

Yücecan S 1988. Kanser Hastalığında Tedavi Amacıyla Kullanılan Yöresel Bitkiler. Beslenme ve Diyet Dergisi 17:111-120.

Zohary M 1973. Geobotanical Foundations of The

Middle East. Vol. 1- 2, Stutgart: Gustav Fischer Verlag. 